UC-920

Issued: July 1993

The Xerolithic Geothermal ("Hot Dry Rock")

Energy Resource of the United States:

An Update

Gregory J. Nunz 


\section{DISCLAIMER}

This report was prepared as an account of work sponsored by an agency of the United States Government. Neither the United States Government nor any agency Thereof, nor any of their employees, makes any warranty, express or implied, or assumes any legal liability or responsibility for the accuracy, completeness, or usefulness of any information, apparatus, product, or process disclosed, or represents that its use would not infringe privately owned rights. Reference herein to any specific commercial product, process, or service by trade name, trademark, manufacturer, or otherwise does not necessarily constitute or imply its endorsement, recommendation, or favoring by the United States Government or any agency thereof. The views and opinions of authors expressed herein do not necessarily state or reflect those of the United States Government or any agency thereof. 


\section{DISCLAIMER}

Portions of this document may be illegible in electronic image products. Images are produced from the best available original document. 


\section{Acknowledgments}

The writer wishes to express his appreciation to Dr. Jerry Conner, Dr. David Duchane, and Mr. Morton Smith for reviewing the manuscript and providing helpful comments. He is also deeply indebted to Dr. Kenneth Wohletz for amassing and screening the data needed for the new geothermal gradient contour map. Special thanks are due Ms. Barbara Hahn, Ms. Regina Johnson, and Ms. Lanoette Piotrowski, who typed the manuscript; Ms. Ruth Robichaud and Mr. John Tubb, who prepared the illustrations; and Ms. Anne Garnett, who edited the report. 


\section{CONTENTS}

Page

ABSTRACT . . . . . . . . . . . . . . . . . . . . . . 1

1. INTRODUCTION . . . . . . . . . . . . . . . . . . . . . . . . . . . 1

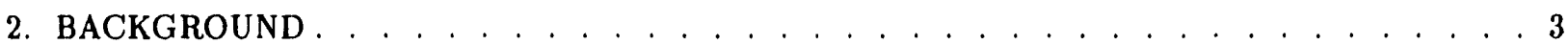

2.1. Fluid-Bearing Resources . . . . . . . . . . . . . . . . . . . . . . . . . . . 3

2.2. Xerolithic Resources . . . . . . . . . . . . . . . . . . . . . . . . . . . . . . 3

2.3. HDR Energy-Extraction Demonstration Projects . . . . . . . . . . . . . . . 3

3. RESOURCE ESTIMATION . . . . . . . . . . . . . . . . . . . . . . . . . . . . . . . . 6

3.1. Definitions. . . . . . . . . . . . . . . . . . . . . . . . 6

3.2. Units . . . . . . . . . . . . . . . . . . . 7

3.3. Analytical Approach . . . . . . . . . . . . . . . . . . . . . . . . . . . . . . . 7

3.4. The Geothermal Gradient Map . . . . . . . . . . . . . . . . . . . . . . . . . . . .8 8

3.5. Resource Calculations . . . . . . . . . . . . . . . . . . . . . . . . . . . . . . . . "8

4. DISCUSSION OF RESULTS . . . . . . . . . . . . . . . . . . . . . . . . . . . . . . 17

5. CONCLUSIONS AND RECOMMENDATIONS . . . . . . . . . . . . . . . . . . . . . . 25

6. REFERENCES . . . . . . . . . . . . . . . . . . . . . . . . 26 APPENDIXES

A. Glossary . . . . . . . . . . . . . . . . . . . . . . . . . . . . . . . . . . . . . . 29

B. Resource Base Computation Algorithms . . . . . . . . . . . . . . . . . . . . . . . . . 30 


\section{FIGURES}

Figure

Page

1. HDR Energy Extraction Concept for Rock with Low Natural Permeability . . . . . . . . . . . 5

2. Geothermal Gradient Contour Map of the United States . . . . . . . . . . . . . . . . . . 11

3. Areal Distribution of Geothermal Gradients in the United States . . . . . . . . . . . . . . . 13

4. Comparison of Potentially Useful HDR Energy Resource Base of the US with Projected WORLD Reserves of Fossil Fuels . . . . . . . . . . . . . . . . . . . . . . . 19

5. Low-Temperature Energy Use in the US and Some Typical Applications . . . . . . . . . . . . 21

6. State Average Areal Densities of Potentially Useful HDR Resource Base . . . . . . . . . . . 23

\section{TABLES}

Table

Page

I. Mean Values for Geothermal Gradient Contour Intervals in Figure $2(\mathrm{~K} / \mathrm{km})$. . . . . . . . . . . . 9

II. Hot Dry Rock Geothermal Energy Resource Base . . . . . . . . . . . . . . . . . . . . . 14

III. HDR Energy Accessible Resource Base . . . . . . . . . . . . . . . . . . . . . . . . . 15

IV. Potentially Useful Hot Dry Rock Geothermal Energy Resource Base . . . . . . . . . . . . . 16 


\title{
THE XEROLITHIC GEOTHERMAL ("Hot Dry Rock") ENERGY RESOURCE OF THE UNITED STATES: AN UPDATE
}

by

\author{
Gregory J. Nunz
}

\begin{abstract}
This report presents revised estimates, based upon the most current geothermal gradient data, of the xerolithic geothermal ("hot dry rock" or HDR) energy resources of the United States. State-by-state tabular listings are provided of the HDR energy resource base, the accessible resource base, and the potentially useful resource base. The latter is further subdivided into components with potential for electricity generation, process heat, and space heat. Comparisons are made with present estimates of fossil fuel reserves. A fullsized geothermal gradient contour map is provided as a supplement in a pocket inside the back cover of the report.
\end{abstract}

\section{INTRODUCTION}

Over the past two decades since its recognition as a potential major source of energy, the xerolithic geothermal energy resource-more popularly known as the "hot dry rock" (HDR) geothermal resource-has been estimated several times (White [1965]; White and Williams [1975]; Muffler [1979a]; Grossling [1972]; Hickel [1972]; Rex and Howell [1973]; National Petroleum Council [1973]; McGetchin [1977]; LASL HDR Project Staff [1978]; Heiken, Goff, and Cremer [1980]; Tester, Brown, and Potter [1989]). Why, then, yet another assessment? There are several aspects to the rationale for generating this document.

First, new geothermal gradient data have become available since the last published national survey (Kron and Stix [1982]), particularly for Alaska and Hawaii, which were not included therein. In the words of the United States Geological Survey (USGS), "Any resource assessment should be periodically updated in response to new information, new assessment methodologies, greater understanding of resource characteristics, improved exploration, extraction, and utilization technologies, and changed economic and social conditions" (Muffler and Christiansen [1978]). Transmitted with this report is an updated geothermal gradient contour map of the United States, which now includes Alaska and Hawaii and on which the contours for the conterminous 48 states have been revised.

Second, with the current data, the resource is estimated "bottoms up" on a state-by-state basis, as well as subsumed by the Department of Commerce's demographic "divisions." This tabular presentation is thus compatible with the department's other published tables of national statistics and would facilitate inclusion of such resource data, when appropriate, in energy-related sections of their publications.

Third, and perhaps most important, this document may serve as a timely reminder. Since accommodation was reached with the $\mathrm{OPEC}^{1}$ cartel in the late 1970s, national awareness of, and interest in, alternative

\footnotetext{
1 Technical terms and acronyms are defined in the glossary, Appendix A.
} 
energy source development has greatly diminished. Yet, although the cognoscenti may disagree in detail about the size and projected endurance of the world's fossil fuel supplies, it is crystal clear that these supplies are exhaustible in the foreseeable future and that petroleum, in particular, could be exhausted in the first half of the next century at the present rate of consumption. As petroleum is the only significant nearterm energy source for serving the transportation sector and is not easily replaceable as a feedstock for many vital organic products, it must be conserved for these purposes and not squandered in the generation of heat for stationary applications. Further, from the environmental perspective, there is a growing concern that the earth cannot tolerate the continual outpouring of carbon dioxide $\left(\mathrm{CO}_{2}\right)$ from the oxidation-combustive or catalytic-of any fossil fuel, because of $\mathrm{CO}_{2}$ 's greenhouse effect. Nor can the earth tolerate the sulfur dioxide $\left(\mathrm{SO}_{2}\right)$ also produced (predominantly by combustion of coal), which leads to acid rain. This consideration also argues for expeditious development of long-lived "clean" alternative energy sources. The ubiquitous geothermal energy of HDR holds the promise of serving a large part of this need.

This report is therefore not primarily directed toward the geology/geophysics fraternity, but rather toward the "movers and shakers." Its intent is to provide them with information and (hopefully) motivation to promote continued development of economical extraction technology for, and subsequent commercial exploitation of, this huge neglected resource. 


\section{BACKGROUND}

Geothermal energy is, in the most general sense, the virtually inexhaustible supply of heat energy contained within the earth's interior. Geothermal energy resources, specifically, are concentrations of this geothermal energy resident in (potentially) accessible subsurface rocks and their indigenous fluids, which are being heated by underlying molten rock and/or proximate radiogenic heat sources. Such resources may be broadly characterized as one of two general types: fluid-bearing or xerolithic. These are further defined and categorized as follows:

\subsection{Fluid-Bearing Resources}

The fluid-bearing resources comprise hydrothermal connective systems and geopressured systems. The hydrothermal convective systems (usually called simply "hydrothermal") include hot water and/or steam that are trapped in porous or highly fractured rock. Hydrothermal systems are further classified as either liquiddominated ("hot water") or vapor-dominated ("steam") systems, depending upon the principal physical state of the fluid. Such systerns are the easiest to exploit because the hot indigenous fluid can simply be tapped by conventional drilling, brought to the surface, and used for the generation of electricity or for heating. Indeed, hydrothermal systems have been used commercially for some time both in the United States (notably The Geysers in California and Klamath Falls in Oregon) and elsewhere in the world (e.g. Iceland, Indonesia, Japan, Mexico, the Philippines, and New Zealand). Currently, hydrothermal-electric power plants are producing more than 5 gigawatts of baseload electricity in addition to comparable amounts of thermal energy for numerous direct heating applications.

The geopressured systems (typified by those found along the Gulf Coast of the US) are sediment-filled reservoirs that also contain indigenous pore fluids at moderately high temperatures but at confining pressures significantly higher than normal hydrostatic. The high pressures promote solubility of gases in the liquid, and much of the potential value of geopressured systems lies in the chemical energy of the sizable quantities of dissolved methane gas contained in their geofluids. To dats, energy extraction from geopressured systems has been demonstrated experimentally but, primarily for reasons of noncompetitive economics, these systems are not being commercially exploited.

\subsection{Xerolithic Resources}

The xerolithic geothermal resources, which are the subject of this report and which we will hereafter refer to by the more mundane and popular name of "hot dry rock" (HDR), are characterized by a lack of naturally occurring in situ geofluid. Whereas the fluid-bearing resources are relatively rare, occurring in only a few fortunate locations, the HDR resource is widespread, comprising essentially "all the rest" (previously estimated at greater than $95 \%$ ) of the total geothermal resource base.

A more formal definition of hot dry rock is that portion of the nnmelted crustal rock underlying a given geographic area which is at temperatures of potential commercial interest but which does not spontaneously produce hot fluids at an adequate rate for economical extraction of its energy. To utilize HDR's energy, it is therefore necessary to "mine" the heat by artificially creating or increasing the permeability of the rock units and by introducing the heat transfer fluid. An HDR reservoir is therefore manmade, as opposed to the fluid-bearing ones, which occur naturally.

\subsection{HDR Energy-Extraction Demonstration Projects}

The foregoing definition implies a wide spectrum of rock types and permeabilities. Indeed, techniques borrowed from the oil and gas industry have been proposed (for instance, 'Tester and colleagues $[1980,1990]$ ) for extracting HDR energy from rock units with various ranges of permeability. However, the only type of formation for which HDR energy extraction has thus far been demonstrated in an engineering sense is lowpermeability crystalline basement rock. The archetypical and flagship demonstration project of this nature is 
the Fenton Hill ${ }^{2}$ HDR Project, which has been carried on at that site in New Mexico by Los Alamos National Laboratory (LANL) since the mid 1970s. This project was initially supported solely by the US Department of Energy (DOE) and its predecessor organizations. In 1980, under a limited-term International Energy Agency agreement, the Fenton Hill Project was expanded into the International Hot Dry Rock Geothermal Energy Development Program with technical participation and additional funding provided by the governments of (then West) Germany through its Kernforschungsanlage-Jülich Gmbh (KFA) and Japan through its New Energy Development Organization (NEDO). Since 1986, the Fenton Hill effort has continued under DOE's sole sponsorship and will probably so continue through its completion. After the Fenton Hill project was well underway, complementary parallel projects were initiated, first in Cornwall, $\mathrm{UK},{ }^{3}$ and subsequently in Japan, Germany, France, and Russia.

The energy extraction technique developed for hot low-permeability rock is conceptually simple. A high surface-to-volume region of flow passages is created in the desired hot rock unit and connected to the surface through one or more each of injection and production wells, effectively producing a subterranean heat exchanger. A closed flow loop is completed by the surface system. Cool water is pumped down the injection well and then returns to the surface, under the pressure level maintained, as superheated water whose energy is extracted by the surface heat exchange device appropriate to the application. The water is then reinjected, completing the cycle as shown in Fig. 1.

Keeping the extracted fluid in a superheated liquid state serves to minimize the pumping power requirements and also to inhibit deleterious scale deposition. Some makeup water must be added to the reinjected fluid to compensate for the small percentage of water lost to the underground formation. In addition to maximizing the energy extraction efficiency (Tester and Herzog [1990]), this closed-loop approach also reduces the operational effluents of the HDR energy system to virtually nil, providing an extremely environmentally clean source of power.

In practice, the underground HDR reservoir is created, with equipment and technology adapted from the oil and gas industry, as follows: (a) the injection well(s) is drilled to the requisite depth for the temperature desired; (b) a 3-dimensional matrix of permanently opened and interconnected fractures and joints is formed by using hydraulic pressure to open and propagate the fracture system in the hot rock unit; and (c) the production well(s) is drilled to appropriately access the fractured region and receive the fluid delivered by the injection well(s). The wells may have somewhat inclined lower sections to afford sufficient fracture volume within the desired temperature regime and, although the conceptual system of Fig. 1 shows only one well pair, a commercial HDR system would utilize one or more injection wells and multiple production wells. The energy extraction concept for low-permeability rock units and the LANL Fenton Hill Project are documented elsewhere in detail by Smith et al. (1975), LASL (now LANL) HDR Staff (1978), Nunz (1980), Heiken et al. (1981), Nunz and Franke (1983, 1987), Smith (1987), and Tester et al. (1989).

${ }^{2}$ A site located about $55 \mathrm{~km}$ west of Los Alamos, NM, on the western rim of the Valles Caldera, a geologically young silicic volcano.

${ }^{3}$ Conducted by the Camborne School of Mines under the sponsorship of the United Kingdom Department of Energy (UKDOE). 


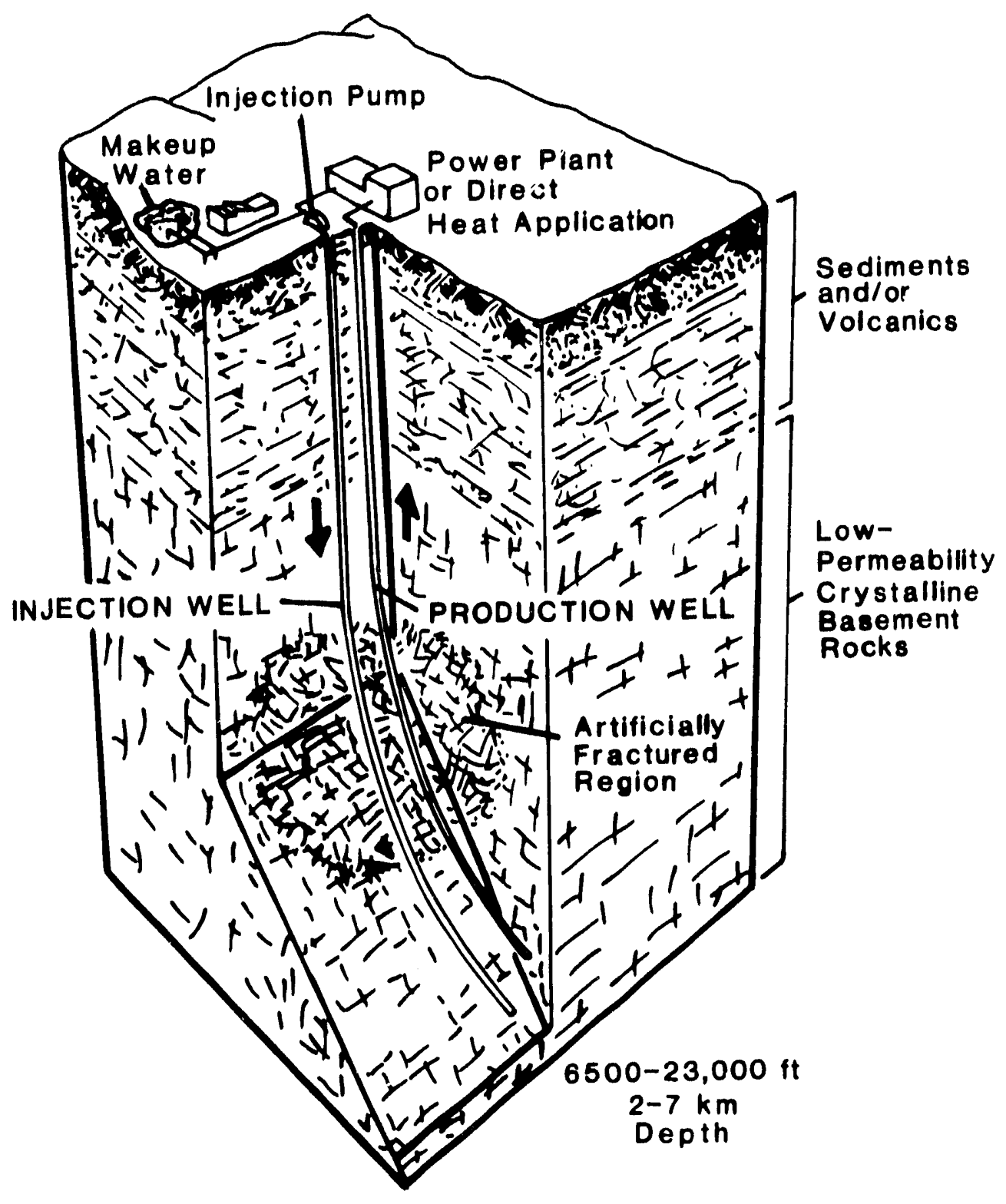

Fig. 1. HDR energy extraction concept for rock with low natural permeability (adapted from Tester et al. [1989]). 


\section{RESOURCE ESTIMATION}

In resource-related discussions by the mining industry, the oil and gas (O\&G) industry, the United States Geological Survey (USGS), and others, there is not general agreement on the definitions of resource terminology. Consequently, it is appropriate at this juncture to introduce and define the terminology used herein specifically to quantify the HDR energy resource.

\subsection{Definitions}

Three terms are used in this report in discussing the size of the United States' HDR energy resource: resource base, accessible resource base, and potentially useful resource base. These are defined and characterized as follows:

Resource Base, $Q_{B}$-all of the heat energy contained in the rock units underlying the specified area or region (exclusive of hydrothermal and geopressured systems) to a depth of $10 \mathrm{~km}$ at temperatures above a reference of $15^{\circ} \mathrm{C}$. This definition is consistent, if not identical, with that of the US Geological Survey (Nathenson and Muffler [1975] and Muffler [1979b]). If all of the requisite temperature and rock property data were available to accurately and incontrovertibly calculate the resource base's value, it would be a fixed and relatively "immortal" number, independent of technology and econornics.

Accessible Resource Base, $Q_{A}$-that part of the resource base at temperatures above $25^{\circ} \mathrm{C}$ down to current routinely drillable depth (conservatively taken herein to be $7 \mathrm{~km}$ ) or the depth at which the critical temperature of water $\left(374^{\circ} \mathrm{C}\right)$ is reached, whichever is less. This definition is modified somewhat from that of the US Geological Survey, here taking $25^{\circ} \mathrm{C}$ (rather than mean annual surface temperature of $15^{\circ} \mathrm{C}$ ) as the reference temperature, and $7 \mathrm{~km}$ (instead of $6 \mathrm{~km}$ ) as the drillable depth. The accessible resource base is meant to be a more "realistic" gross measure of the resource than is the resource base. However, note that because of the depth limit specification, $Q_{A}$ is technology dependent and hence, indirectly, also economics dependent, which ultimately results in its being a time-variable quantity.

Potentially Useful Resource Base, $Q_{U}$-that part of the accessible resource base that could potentially be used for either electricity generation or direct heat applications, assuming a minimum process rejection temperature of $40^{\circ} \mathrm{C}$. This quantity, $Q_{U}$, is peculiar to this report and is intended to give a still more realistic measure of the fraction of the resource base that might be commercially exploitable under appropriate economic circumstances. $Q_{U}$ is divided into useful resource with potential for electricity generation (PEG), $Q_{U E}$, and useful resource for direct applications of thermal energy (DATE), $Q_{U D}$. The latter is, in turn, subdivided into process heat potential, $Q_{U P}$, and space heating potential, $Q_{U S}$.

Thus

$$
\begin{aligned}
Q_{U} & \equiv Q_{U E}+Q_{U D} \\
& =Q_{U E}+Q_{U P}+Q_{U S} .
\end{aligned}
$$

The temperature regimes associated with these components of $Q_{U}$ are taken, somewhat arbitrarily, to be

PEG: 150 to $370^{\circ} \mathrm{C}$

DATE: 60 to $150^{\circ} \mathrm{C}$, of which

PROCESS HEAT: 100 to $150^{\circ} \mathrm{C}$

SPACE HEAT: 60 to $100^{\circ} \mathrm{C}$.

Like $Q_{A}, Q_{U}$ is dependent upon then-current drilling and energy conversion technology and its associated economics. 


\subsection{Units}

In keeping with current practice, the resource base data are computed and reported herein in the SI (Système International d'Unités) energy units of exajoules. For readers familiar with previously published values in quads, the conversion is

$$
1 \text { exajoule }=10^{18} \text { joules }=9.479 \times 10^{14} \mathrm{Btu}=0.9479 \text { quad }
$$

or, roughly speaking, 1 exajoule is about equal to 1 quad. Because most persons do not have a "feel" for exajoules (or quads) -an uncommon measure of energy in industrial parlance-approximate equivalents are given where appropriate in crude oil equivalent (COE) and/or coal equivalent, on the basis of their industry-specified nominal energy content:

$$
\begin{aligned}
1 \text { exajoule } & \approx 176 \text { million barrels, } \mathrm{COE} \\
& \approx 44.36 \text { million (short) tons, coal equivalent. }
\end{aligned}
$$

In addition to these direct energy conversion factors, which are most appropriate for the DATE part of $Q_{U E}$, we cite the electricity generation capability in gigawatt-years, using the US Department of Commerce (1991) standard factor for geothermal generation of electricity, $2.1096 \times 10^{3} \mathrm{Btu} / \mathrm{kW}-\mathrm{h}$. This present electricity generation conversion factor, which implies a $16.2 \%$ overall conversion efficiency (and is also therefore technology dependent), is then

$$
1 \text { exajoule } \underset{\text { yields }}{\Longrightarrow} 44.93 \text { billion kilowatt-hour }=5.129 \text { gigawatt-year } \text {. }
$$

These equivalents are especially helpful in comparing the HDR resource with other energy resources.

\subsection{Analytical Approach}

Each of the resource measures reported was calculated, on a state-by-state basis, with an equation of the form

$$
Q=\sum_{i} \Delta A_{i} \int_{z_{\min , i}}^{z_{\max , i}} \overline{\rho C_{p_{i}}}(z)\left[\left(T_{0}+\overline{\nabla T_{i}} z\right)-T_{r e f}\right] d z
$$

where

$Q \quad$ represents any of the resource measures defined;

$\Delta A_{i} \quad$ is the total area of region(s) within the state over which the average geothermal gradient is assumed constant at $\nabla T_{i}$;

$\overline{\rho C_{p_{i}}}(z)$ is the average volumetric-specific heat of the rock under the $i$ th region, as a function of depth;

$T_{0} \quad$ is the mean annual surface temperature, herein taken, in all cases, to be $15^{\circ} \mathrm{C}$;

$\nabla T_{i} \quad$ is the average geothermal gradient, $\frac{\partial T}{\partial z}$, assumed constant over the depth range of interest for the $i$ th region;

$T_{\text {ref }} \quad$ is the assumed "reference" temperature, representing the minimum temperature of interest, or minimum process rejection temperature, for that resource measure; and

$z$ is depth, measured from the surface, integrated over the range $z_{\min , i}$ to $z_{\max , i}$ for the $i$ th region.

Values for the demographic "divisions," the conterminous 48 states, and the entire United States were then computed by summation of the values for the applicable states. The mathematical details are discussed in Appendix B. 


\subsection{The Geothermal Gradient Map}

In computing the measures of the HDR resource, one of the key variables-probably the single most important variable-is the rock temperature. In actuality, this temperature varies continuously with location (i.e., latitude and longitude) as well as with depth. An impractical infinitude of measurements would be required to accurately define this temperature field. The vector that characterizes the rate of change of rock temperature with distance is the geothermal gradient, $\nabla T$. Because the rock temperature at a given depth does not normally change very rapidly with small variations in location (latitude and/or longitude), those components of the gradient are usually assumed negligible and the gradient's magnitude, $\nabla T$, is then essentially the rate of increase of rock temperature with depth, $\frac{\partial T}{\partial z}$. The magnitude of the gradient itself changes with both location and depth and, at any given location, the temperature at a depth $z_{1}$ would be computed as

$$
T\left(z_{1}\right)=T_{0}+\int_{0}^{z_{1}} \nabla T d z
$$

assuming that $\nabla T$ were known as a function of $z$ for that location. An accurate specification of $\nabla T$ everywhere in a geographic aiea to some prescribed depth would likewise require an impractically large set of measurements. Fortunately, unless local peculiarities in the rock strata cause abrupt changes in their bulk thermal conductivity, the temperature profiles to depths of interest are approximately linear, and the magnitude of the gradient can be treated as having an approximately constant value, $\nabla T$, over a finive geographic area. The temperature at any depth, $z_{1}$, within the limits of applicability of such a constant $\overline{\nabla T}$, is then simply $T\left(z_{1}\right) \approx T_{0}+\overline{\nabla T} z_{1}$. Geologists and geophysicists can determine average gradients from downhole thermal measurements, exploiting existing O\&G well or deep-water-well data where possible and drilling occasional ad hoc test wells when necessary. The resulting data can be usefully presented in the form of a geothermal gradient contour map.

Since the upsurge of interest during the 1970s in geothermal energy as an alternative energy source, US gradient data have been systematically compiled and several gradient maps have been published, notably those of Kron and Stix (1982) and of Nathenson and Guffanti (1988) for the conterminous 48 states andmost recently - that of Kron, Wohletz, and Tubb (1991) for the entire US. The latter is herein reproduced in miniature as Fig. 2 and also presented as a full-sized map in the pocket inside the back cover of this report. The gradients, in units of kelvins per kilometer $(\mathrm{K} / \mathrm{km})$ or, equivalently, celsius degrees per kilometer $\left(\mathrm{C}^{\circ} / \mathrm{km}\right)$, are shown in five colored contour intervals. The contours on this map represent the aggregation and smoothing of some 1800 data points and served as the basis for the present resource estimates.

\subsection{Resource Calculations}

The areal integration of the contoured regions in Fig. 2 for each state was performed graphically. The detailed calculations for each state and for the Bureau of Census demographic divisions, the conterminous 48-state area, and the entire US were then done with a Lotus 1-2-3 ${ }^{\mathrm{TM}}$ spreadsheet. Data for a "Pacific Subdivision," comprising the Pacific Division without Alaska and Hawaii, were also tabulated to facilitate computations for the conterminous 48 states.

To use the contour-derived data, it was necessary to assign a single representative gradient value to each of the contour intervals. As the cumulative frequency-vs-log gradient histogram of Fig. 3 shows, the areal distribution of the gradients is approximately log-normal over the actual range of gradients encountered. Consequently, the geometric mean gradient was used to represent each contour interval in the calculations. Because of the wide logarithmic bandwidth of the first contour interval, "zero" to $14 \mathrm{~K} / \mathrm{km}$ (there are no actual $0 \mathrm{~K} / \mathrm{km}$ data points!), and the unspecified upper limit of the fifth contour interval, "60+" $\mathrm{K} / \mathrm{km}$, these two ranges were examined in more detail. As a result of the overall geographic pattern of gradient distribution, it was found to be more appropriate to assign slightly different mean values to the $0-14 \mathrm{~K} / \mathrm{km}$ 
interval for the eastern and western US. The interval-mean values used in the calculations are listed in Table I. These contour intervals also lend themselves conveniently to the resource classification scheme of Tester and Herzog (1990).

The resource base data computed via Eq. (2), under the assumptions of Appendix B, are listed in Table II. The accessible resource base data, as defined in Section 3.1, are listed in Table III. Here, in addition to the standard unit of exajoules, the approximate COE and coal equivalents, in trillions $\left(\times 10^{12}\right)$ of barrels and short tons respectively, are given.

Finally, Table IV presents the potentially useful rescurce base. The "potential for electricity generation" component and those for direct applications of thermal energy are cited separately, as well as the total. For the PEG component, the approximate quantity of electric energy that could be produced therefrom, allowing for conversion efficiencies, is given in thousands of gigawatt-years $\left(\mathrm{GW}_{\mathrm{e}}-\mathrm{yr}\right)$. The DATE component is presented under "process heat" and "space heat" headings. These classifications assume that all of the heat available at high enough temperature would be assigned to electricity generation (it could, of course, be used for DATE) and of the remainder, that in the intermediate temperature range would indeed all be used for process heat, with the low-grade residuum then relegated to space heating. For subsequent comparisons, the grand total $Q_{U}$ is also converted to its COE and coal equivalent.

In principle, in computing $Q_{B}, Q_{A}$, and $Q_{U}$, the US Geological Survey's estimated hydrothermal and geopressured resource bases (Muffler [1979b]) should have been subtracted out. They are, however, so small in comparison with the HDR resource that, within the accuracy of these calculations, this minor correction can reasonably be ignored.

Table I.

Mean Values for Geothermal Gradient Contour Intervals in Figure $2(\mathrm{~K} / \mathrm{km})$

Mean Value Resource

\section{Contour Interval Eastern US Western US Classification}

$\begin{array}{rccl}0-14 & 10.2 & 10.7 & \text { Marginal } \\ 15-29 & 21.2 & 21.2 & \text { Low-Grade } \\ 30-44 & 36.5 & 36.5 & \text { Low-Grade } \\ 45-59 & 51.6 & 51.6 & \text { Mid-Grade } \\ 60+ & - & 81.5 & \text { High-Grade }\end{array}$




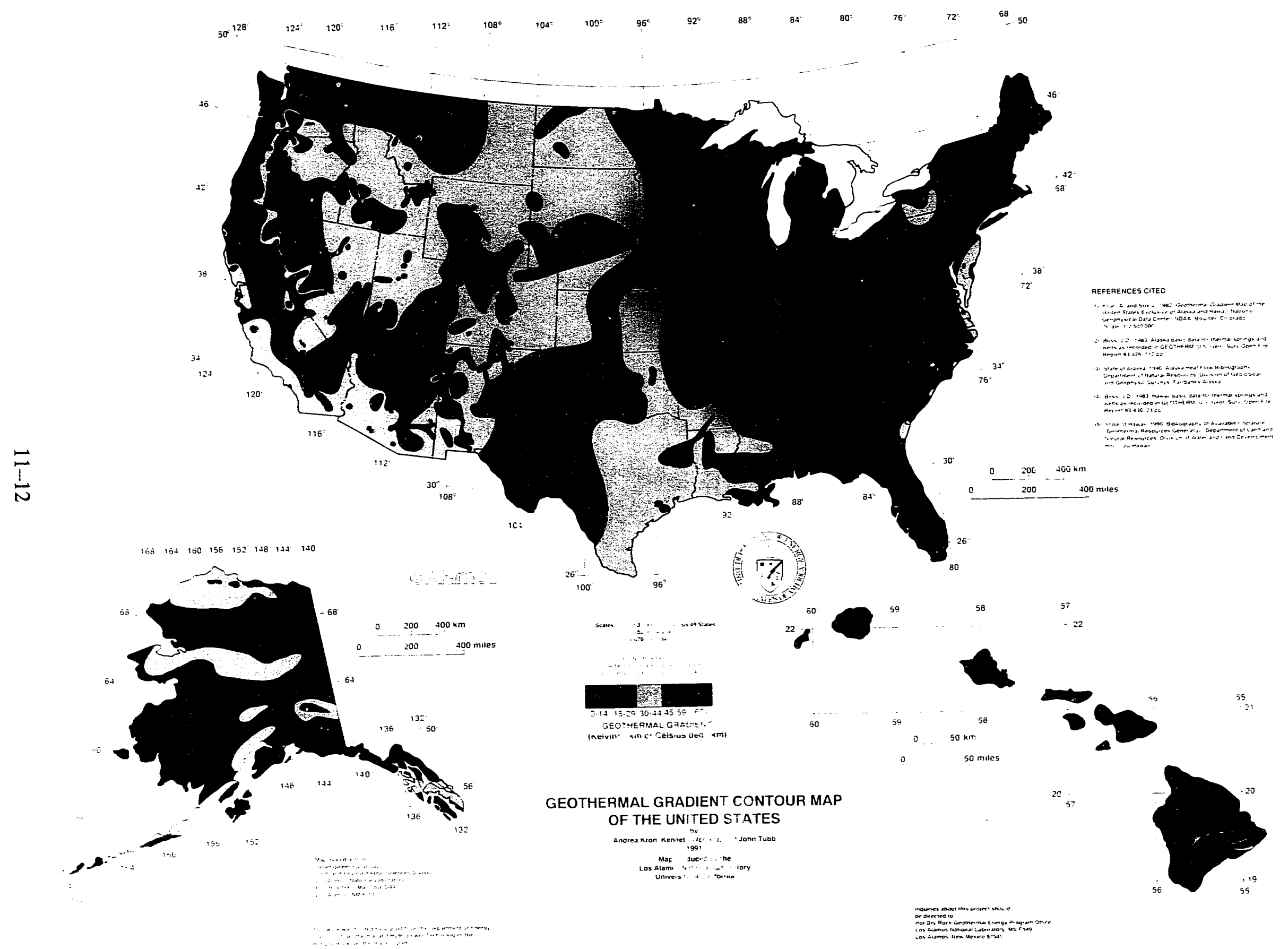

Fig. 2. Geothermal gradient contour map of the United States. 


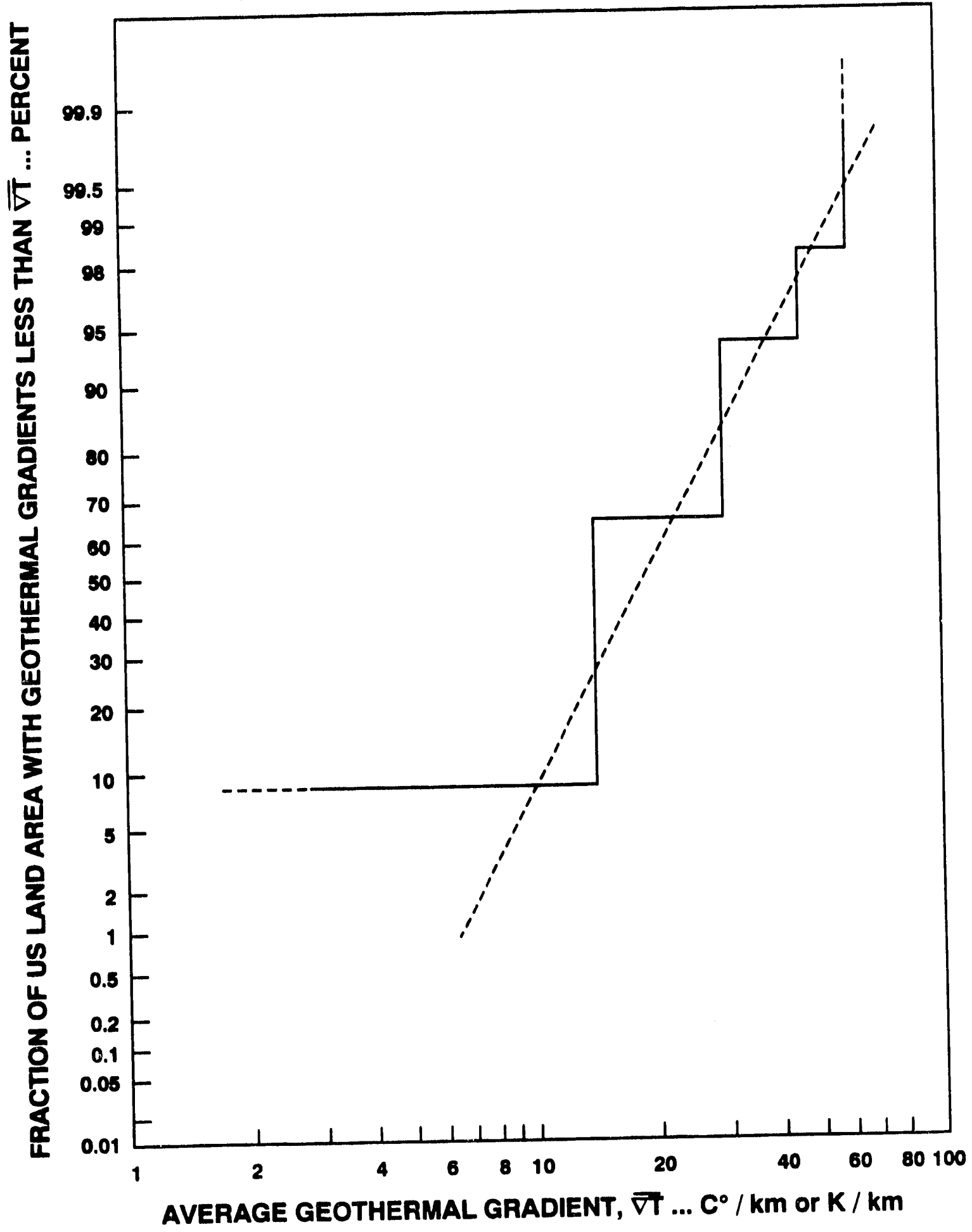

Fig. 3. Areal distribution of geothermal gradients in the United States. 
Table II.

Hot Dry Rock Geothermal Ėnergy Resource Base (thousands of exajoules)

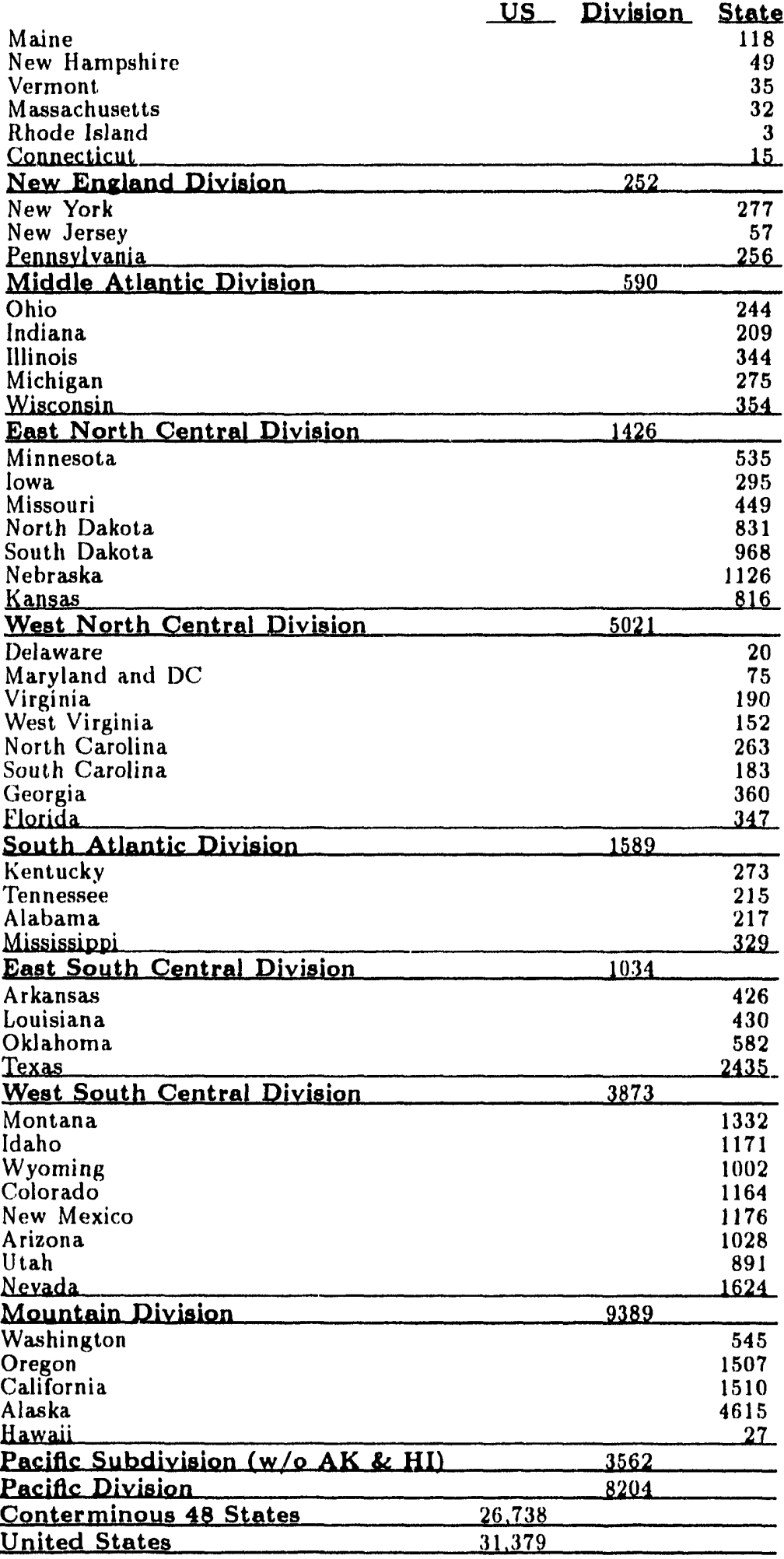


Table III.

HDR Energy Accessible Resource Base ${ }^{a}$

\begin{tabular}{|c|c|c|c|}
\hline & $\begin{array}{c}\text { Thousands of } \\
\text { Exajoules } \\
\end{array}$ & $\begin{array}{l}\text { Trillions of Barrels, } \\
\text { Oil Equivalent }\end{array}$ & $\begin{array}{l}\text { Trillions of Tons, } \\
\text { Coal Equivalent }\end{array}$ \\
\hline Maine & 45 & 7.9 & 2.0 \\
\hline New Hampshire & 20 & 3.5 & 0.9 \\
\hline Vermont & 13 & 2.3 & 0.6 \\
\hline Massachusetts & 12 & 2.2 & 0.5 \\
\hline Rhode Island & 1 & 0.2 & 0.05 \\
\hline Connecticut & 5 & 1,0 & 0.2 \\
\hline New Encland Division & 97 & 17.1 & 4.3 \\
\hline New York & 113 & 19.9 & 5.0 \\
\hline New Jersey & 24 & 4.2 & 1.1 \\
\hline Pennsylyania & 104 & 18.3 & 4.6 \\
\hline Middle Atlantic Division. & 241 & 42.3 & 10.7 \\
\hline Oho & 100 & 17.6 & 4.4 \\
\hline Indiana & 85 & 15.0 & 3.8 \\
\hline Illinois & 141 & 24.9 & 6.3 \\
\hline Michigan & 110 & 19.3 & 4.8 \\
\hline Wisconsin & 146 & 25.7 & 6.5 \\
\hline East North Central Division & 582 & 102.5 & 25.8 \\
\hline Minnesota & 222 & 39.1 & 9.8 \\
\hline lowa & 119 & 20.9 & 5.3 \\
\hline Missouri & 186 & 32.7 & 8.2 \\
\hline North Dakota & 357 & 62.8 & 15.8 \\
\hline South Dakota & 417 & 73.3 & 18.5 \\
\hline Nebraska & 484 & 85.2 & 21.5 \\
\hline Kansas & 348 & 61.2 & 15.4 \\
\hline West North Central Division & 2132 & 375.2 & 94.5 \\
\hline Delaware & 9 & 1.5 & 0.4 \\
\hline Maryland and DC & 31 & 5.5 & 1.4 \\
\hline Virginia & 75 & 13.2 & 3.3 \\
\hline West Virginia & 63 & 11.0 & 2.8 \\
\hline North Carolina & 106 & 18.7 & 4.7 \\
\hline South Carolina & 75 & 13.2 & 3.3 \\
\hline Georgia & 148 & 26.0 & 6.6 \\
\hline Elorida & 143 & 25.2 & 6.3 \\
\hline South Atlantic Division & 650 & 114.3 & 28.8 \\
\hline Kentucky & 113 & 20.0 & 5.0 \\
\hline Tennessee & 86 & 15.2 & 3.8 \\
\hline Alabama & 85 & 14.9 & 3.7 \\
\hline Mississippi & 137 & 24.0 & 6.1 \\
\hline East South Central Division & 421 & 74.1 & 18.7 \\
\hline Arkansas & 179 & 31.6 & 8.0 \\
\hline Louisiana & 183 & 32.2 & 8.1 \\
\hline Oklahoma & 245 & 43.2 & 10.9 \\
\hline Texas & 1033 & 181.8 & 45.8 \\
\hline West South Central Division & 1640 & 288.8 & 72.8 \\
\hline Montana & 565 & 99.4 & 25.0 \\
\hline Idaho & 503 & 88.5 & 22.3 \\
\hline Wyoming & 428 & 75.3 & 19.0 \\
\hline Colorado & 498 & 87.7 & 22.1 \\
\hline New Mexico & 499 & 87.8 & 22.1 \\
\hline Arizona & 435 & 76.6 & 19.3 \\
\hline Utah & 381 & 67.0 & 16.9 \\
\hline Nevada & 695 & 122.4 & 30.8 \\
\hline Mountain Division & 4004 & 704.7 & 177.6 \\
\hline Washington & 229 & 40.3 & 10.2 \\
\hline Oregon & 646 & 113.7 & 28.6 \\
\hline California & 639 & 112.5 & 28.4 \\
\hline Alaska & 1940 & 341.4 & 86.0 \\
\hline Hawaii & 10 & -1.8 & 0.5 \\
\hline Paciflc Subdivision (w/o AK \& $\mathrm{HI}$ ) & 1514 & 266.5 & 67.2 \\
\hline Paciflc Division & 3464 & 609.7 & 1537 \\
\hline Conterminous 48 States & 11.281 & 1.985 .5 & 5004 \\
\hline United States & 13,231 & 2.328 .7 & 587.0 \\
\hline
\end{tabular}

${ }^{a}$ Division and continental totals may not agree exactly, because of rounding.

${ }^{b} 42$-gallon (159-liter) barrel; 1 trillion (American) $=10^{12}$.

${ }^{c}$ Short ton $(2000 \mathrm{lbm}=907.2 \mathrm{~kg})$. 
Thble IV.
Potentially Useful Hot Dry Rock Geothermal Energy Resource Base ${ }^{\alpha}$

$$
\text { Potential Bectricity }
$$

Ceneration $\quad$ Direct Application

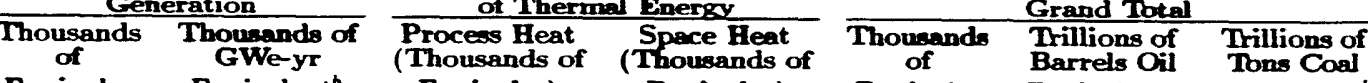

\begin{tabular}{|c|c|c|c|c|c|c|c|}
\hline $\begin{array}{l}\text { Maine } \\
\text { New Hampshire } \\
\text { Vermont } \\
\text { Massachusetts } \\
\text { Rhode Island } \\
\text { Connecticut }\end{array}$ & $\begin{array}{c}\text { Exajoules } \\
3 \\
3 \\
1 \\
1 \\
\sim 0.1 \\
\sim 0\end{array}$ & $\begin{array}{c}\text { Equivalent }^{b} \\
17 \\
15 \\
5 \\
6 \\
\sim 0.4 \\
\end{array}$ & $\begin{array}{c}\text { Exajoules) } \\
9 \\
8 \\
2 \\
3 \\
\sim 0.2 \\
\end{array}$ & $\begin{array}{c}\text { Exajoules) } \\
15 \\
4 \\
4 \\
4 \\
\sim 0.5 \\
2 \\
\end{array}$ & $\begin{array}{c}\text { Exaioules } \\
2 \overline{1} \\
15 \\
8 \\
8 \\
\sim 0.5 \\
3 \\
\end{array}$ & $\begin{array}{c}\text { Equivalent } \\
5 \\
3 \\
1 \\
1 \\
\sim 0.1 \\
\sim 0.5 \\
\end{array}$ & $\begin{array}{c}\text { Equivalent }^{d} \\
1 \\
\sim 0.7 \\
\sim 0.4 \\
\sim 0.3 \\
\sim 0.02 \\
\sim 0.1 \\
\end{array}$ \\
\hline New England Division & 8 & 43 & 22 & 30 & 61 & 11 & $\frac{3}{3}$ \\
\hline New York & 31 & 157 & 34 & 21 & 85 & 15 & 4 \\
\hline $\begin{array}{l}\text { New Jersey } \\
\text { Pennsylvania }\end{array}$ & $\begin{array}{r}12 \\
23 \\
\end{array}$ & $\begin{array}{r}59 \\
117 \\
\end{array}$ & $\begin{array}{r}5 \\
3.5 \\
\end{array}$ & $\begin{array}{r}3 \\
20 \\
\end{array}$ & $\begin{array}{l}19 \\
78 \\
\end{array}$ & $\begin{array}{r}3 \\
14 \\
\end{array}$ & $\frac{1}{3}$ \\
\hline Middle Atlantic Division & 65 & 333 & 74 & 44 & 182 & 32 & 8 \\
\hline $\begin{array}{l}\text { Ohio } \\
\text { Indiana }\end{array}$ & $\begin{array}{l}16 \\
15\end{array}$ & $\begin{array}{l}80 \\
78\end{array}$ & 42 & $\begin{array}{l}18 \\
16\end{array}$ & $\begin{array}{l}76 \\
64\end{array}$ & 13 & $\begin{array}{l}3 \\
3\end{array}$ \\
\hline Illinois & 32 & 65 & 52 & 24 & $\begin{array}{c}64 \\
108\end{array}$ & 19 & $\frac{3}{5}$ \\
\hline $\begin{array}{l}\text { Michigan } \\
\text { Wisconsin }\end{array}$ & 14 & $\begin{array}{l}70 \\
106\end{array}$ & 36 & 26 & 77 & 13 & 3 \\
\hline East North Central Division & 101 & $\frac{1.0}{519}$ & $\frac{66}{229}$ & $\frac{24}{109}$ & $\frac{114}{439}$ & 20 & $\frac{5}{19}$ \\
\hline Minnesota & 46 & 233 & 94 & 34 & $\frac{439}{174}$ & $\frac{\pi}{31}$ & $\frac{19}{8}$ \\
\hline Iowa & 19 & 98 & 40 & 27 & 86 & $\begin{array}{l}31 \\
15\end{array}$ & $\begin{array}{l}8 \\
4\end{array}$ \\
\hline Missouri & 33 & 167 & 82 & 30 & 145 & 25 & $\begin{array}{l}4 \\
6\end{array}$ \\
\hline $\begin{array}{l}\text { North Dakota } \\
\text { South Dakota }\end{array}$ & $\begin{array}{l}243 \\
293\end{array}$ & $\begin{array}{l}1246 \\
1502\end{array}$ & 51 & 19 & 313 & 55 & 14 \\
\hline $\begin{array}{l}\text { Nouth Wakota } \\
\text { Nebraska }\end{array}$ & $\begin{array}{l}293 \\
319\end{array}$ & $\begin{array}{l}1502 \\
1638\end{array}$ & 52 & $\begin{array}{l}19 \\
20\end{array}$ & $\begin{array}{l}363 \\
392\end{array}$ & $\begin{array}{l}64 \\
69\end{array}$ & 16 \\
\hline Kansas & 198 & 1015 & 73 & 26 & 297 & 52 & 13 \\
\hline West North Central Division & 1150 & 5900 & 445 & 176 & 1771 & 312 & 78 \\
\hline Delaware & 5 & 25 & 2 & $\sim 0.6$ & $\frac{i}{1}$ & 1 & $\sim 0.3$ \\
\hline Maryland \& DC & 12 & 64 & פר. & 4 & 25 & 4 & 1 \\
\hline Wigint Virginia & $\begin{array}{l}14 \\
10\end{array}$ & 53 & 20 & $\begin{array}{l}18 \\
11\end{array}$ & 52 & $\begin{array}{l}9 \\
9\end{array}$ & $\frac{2}{2}$ \\
\hline & 20 & 101 & 36 & 22 & 78 & 14 & $\overline{3}$ \\
\hline South Carolina & 13 & 66 & 31 & 13 & 57 & 10 & 3 \\
\hline $\begin{array}{l}\text { Georgia } \\
\text { Florida }\end{array}$ & 28 & 144 & 60 & 26 & 114 & 20 & 5 \\
\hline South Atlantic Division & 126 & 647 & 248 & $\frac{24}{118}$ & $\frac{111}{492}$ & $\frac{20}{87}$ & $\frac{5}{22}$ \\
\hline Kentucky & 26 & 134 & $4 \pi 8$ & 17 & 90 & 16 & 4 \\
\hline $\begin{array}{l}\text { Tennessee } \\
\text { Alabama }\end{array}$ & $\begin{array}{r}14 \\
9\end{array}$ & $\begin{array}{l}72 \\
44\end{array}$ & $\begin{array}{l}29 \\
23\end{array}$ & 19 & 62 & 11 & 3 \\
\hline Mississiopi & 38 & 195 & 51 & 20 & 109 & 19 & $\frac{2}{3}$ \\
\hline East South Central Division & 87 & 445 & 150 & 80 & 316 & 56 & 14 \\
\hline $\begin{array}{l}\text { Arkansas } \\
\text { Louisiana }\end{array}$ & 74 & 378 & 54 & 20 & 148 & 26 & 3 \\
\hline $\begin{array}{l}\text { Louisiana } \\
\text { Oklahoma }\end{array}$ & $\begin{array}{l}102 \\
107\end{array}$ & $\begin{array}{l}521 \\
547\end{array}$ & 40 & 14 & 156 & $2 \vec{\imath}$ & $i$ \\
\hline $\begin{array}{l}\text { Uilahoma } \\
\text { Texas }\end{array}$ & 534 & 2737 & 246 & $\begin{array}{l}26 \\
92 \\
\end{array}$ & $\begin{array}{l}204 \\
872\end{array}$ & 153 & $\begin{array}{r}99 \\
39\end{array}$ \\
\hline West South Central Division & 816 & 4183 & 411 & 152 & 1379 & 243 & 61 \\
\hline Montana & 283 & 1451 & 140 & 51 & 475 & 84 & 21 \\
\hline Idaho & 310 & $158 \overline{-}$ & 58 & 21 & 388 & 68 & 17 \\
\hline $\begin{array}{l}\text { Wyoming } \\
\text { Colorado }\end{array}$ & $\begin{array}{l}253 \\
311\end{array}$ & $\begin{array}{l}1298 \\
1595\end{array}$ & 83 & 31 & 367 & 65 & 16 \\
\hline New Mexico & 263 & 1349 & 112 & 43 & 417 & 75 & $\begin{array}{l}19 \\
19\end{array}$ \\
\hline Arizona & 208 & 1067 & 113 & 41 & 362 & 64 & 16 \\
\hline $\begin{array}{l}\text { Ctah } \\
\text { Nevada }\end{array}$ & $\begin{array}{l}228 \\
350\end{array}$ & 1170 & 69 & $\begin{array}{l}26 \\
30\end{array}$ & $\begin{array}{l}323 \\
459\end{array}$ & 57 & 14 \\
\hline Mountain Division & 2205 & 11312 & 739 & 274 & $\frac{459}{3219}$ & $\frac{81}{567}$ & $\frac{20}{143}$ \\
\hline Washington & 88 & 453 & 71 & 26 & 185 & 33 & $\frac{170}{8}$ \\
\hline $\begin{array}{l}\text { Oregon } \\
\text { California }\end{array}$ & $\begin{array}{l}332 \\
291\end{array}$ & 1703 & $\begin{array}{r}69 \\
143\end{array}$ & 25 & 426 & 75 & 19 \\
\hline Alaska. & 749 & 3844 & 612 & 223 & 1584 & 279 & $\frac{22}{70}$ \\
\hline Hawaii & 2 & 9 & $\sim 0.8$ & 3 & 6 & 1 & $\sim 0.3$ \\
\hline Pacific Subdivision (w/o AK \& KII) & 712 & 3650 & 282 & 108 & 1102 & 194 & 49 \\
\hline Pacific Division & 1453 & 7503 & 895 & 334 & 2692 & 474 & 119 \\
\hline Conterminous 48 States & 5270 & 270.32 & 2601 & 1091 & 8963 & $15 \pi$ & 398 \\
\hline United States & 6022 & 30886 & 3214 & 1317 & 10553 & 1857 & 468 \\
\hline
\end{tabular}

Division. continent, and application totals may not agree exactly because of rounding.

Conver with Us Deothermal energy:

1 exajoule $=0.9749$ quad(rillion Btu) will produce 44.93 bilion $k$ lle- $h=5.129$ Glle-yr.

42 gallon (159 liter) barret; 1 trillion

Short ton $(2000 \mathrm{lb}=907.2 \mathrm{~kg})$ 


\section{DISCUSSION OF RESULTS}

Before the resource bases were computed, several areal average geothermal gradients were calculated as a "sanity check" on the fundamental data. Specifically the average gradients were determined for the Eastern US, Western US (with and without Alaska and Hawaii), the conterminous 48 states, and the entire country. The results were as follows:

$\begin{array}{ll}\text { Eastern US: } & \nabla T \approx 20 \mathrm{~K} / \mathrm{km} \\ \text { Western US: (w/o AK \& HI) } & \nabla T \approx 33 \mathrm{~K} / \mathrm{km} \\ \text { Western US: (with AK \& HI) } & \nabla T \approx 31 \mathrm{~K} / \mathrm{km} \\ \text { Conterminous 48 States: } & \nabla T \approx 27.7 \mathrm{~K} / \mathrm{km} \\ \text { US: } & \nabla T \approx 27.3 \mathrm{k} / \mathrm{km}\end{array}$

These values are comparable with, if not exactly the same as, those estimated earlier by the USGS, LANL, and others, which cluster around $25 \mathrm{~K} / \mathrm{km}$ for the conterminous 48 states and which Nathenson and Guffanti (1988) report as $25 \mathrm{~K} / \mathrm{km}$ and $34 \mathrm{~K} / \mathrm{km}$, respectively, for the Eastern and Western US.

The overall US resource base figure, $Q_{B} \approx 31.4$ million exajoules, given in Table II, is of the same order of magnitude as earlier estimates: $33 \pm 4$ million EJ (Diment et al. [1975]); 13.7 million EJ above $50^{\circ} \mathrm{C}$ (LASL HDR Project Staff [1978]); 36.5 million EJ (Electrical Power Research Institute [1978]); 6.3 million EJ regional resource base at gradients $\geq 30 \mathrm{~K} / \mathrm{km}$ (Heiken et al. [1982]); 16.9 million EJ to $7 \mathrm{~km}$ (Muffler [1979b]); and 10.5 million EJ above $150^{\circ} \mathrm{C}$ (Tester et al. [1989]). The value of $Q_{B}$ is, from a practical standpoint, unimportant, except as a gross figure of merit to roughly characterize the magnitude of a given energy resource. For HDR energy, $Q_{B}$ is-by anyone's computation and even under the most conservative assumptions-enormous. This realization is what prompted the US Department of Energy and other alternative energy developers worldwide to explore the potential of HDR energy extraction systems.

The accessible resource base, $Q_{A}$, is a more conservative, and somewhat more meaningful, figure of merit for the resource in that it recognizes limitations in physical accessibility -in this case drillable depth-and rejection temperature. The "routinely drillable" depth is here assumed to be $7 \mathrm{~km}$ or the depth at which the critical temperature of water $\left(648 \mathrm{~K}\right.$ or $\left.374^{\circ} \mathrm{C}\right)$ prevails, whichever is less. Both of these are conservative limitations because several boreholes in recent years liave been drilled to depths greater that $7 \mathrm{~km}(23,000$ $\mathrm{ft}$ ) and the temperature limit applies only to the present superheated-liquid extraction loop technique being developed by LANL and in related projects elsewhere. Need-driven technology developments could greatly mitigate these restrictions. The $25^{\circ} \mathrm{C}$ reference temperature is somewhat more realistic than the $15^{\circ} \mathrm{C}$ mean annual surface temperature reference used for $Q_{B}$ but is optimistic as a commercial process rejection temperature, even for low-grade space heating applications. However, the depth conservatism dominates the reference temperature optimism, making $Q_{A}$ still a useful single figure of merit for a given geographic region with an eye toward future technology developments. The $Q_{A}$ value of 13.2 million EJ for the US reported in Table III is comparable with the 14 million EJ between 3 and $7 \mathrm{~km}$ estimated by Muffler (1979). Table III includes the $Q_{A}$ value's $\mathrm{COE}$ and coal equivalents to facilitate inter-resource comparisons.

The resource base information that is probably the most useful to the resource development planner, however, is what we have herein termed the potentially useful resource base, $Q_{U}$, and its components, as identified in Table IV. These values in EJ represent the same conservative depth assumptions as used for $Q_{A}$ but, in addition, embody a still more conservative assumed reference temperature of $40^{\circ} \mathrm{C}$. As noted previously, the PEG and DATE components assume that all of the energy available at high enough temperatures would indeed be earmarked for electricity generation. The electricity generation "equivalent," which was calculated using the present factor for generation from hydrothermal systems, does not assume any improvement in conversion efficiency in future HDR applications. Even so, if it were all available, the 
30.9-million $\mathrm{GW}_{\mathrm{e}}$-yr equivalent would supply the electricity demands of the entire US at the present rate of demand ( 2.7 trillion $\left.k W^{-}-h / y r\right)$ for many thousands of years!

The DATE components of $Q_{U}$ cited in Table IV are likewise very large. Specifically, a process heat potential $Q_{U P}$ of some 3.2 million EJ and a space heat potential $Q_{U S}$ of about 1.3 million EJ are available for the US as a whole.

The last three columns of Table IV give the total value of $Q_{U}$-PEG plus DATE components-and its crude oil and coal equivalents. The reader can acquire some "feel" for significance of these numbers by referring to Fig. 4. The left half of this figure compares the US crude oil equivalent of $Q_{U}$ (from Table IV) with the current world reserve oil and gas $\mathrm{COE}$ (note logarithmic scale!) and shows that the former is more than 1000 times greater than the latter. The present US oil and gas reserve (Energy Information Administration [1990]) is only 61.9 billion barrels COE, with $Q_{U} 30,000$ times as large.

Of course a major fraction of the O\&G reserve, most of which is petroleum, is r eeded for transportation and, to a lesser degree, petrochemical feedstocks. These uses, currently ahout two thirds of the total annual O\&G consumption, cannot easily be replaced by alternatives in the near fiture. However, the remaining one-third, which is devoted to DATE uses, could be provided by HDR energy instead, extending the life of the O\&G reserve by $50 \%$. New technology developments in the first half of the 21 st century, such as possible electrification of the roads and derivation of current petrochemicals from other organic starting materials, might then allow HDR energy and other alternatives to supplant an even larger part of the O\&G demand.

The right half of Fig. 4 similarly shows that the US coal equivalent of $Q_{U}$ is over 300 times greater than the world reserve of coal. US coal consumption is now at a record high of about 893 million short tons per year, most of which is consumed for electricity generation and process and space heating and of which a significant fraction could be replaced by HDR energy, given the necessary development. Of particular interest in this regard is the low-temperature (i.e., low-grade) DATE consumption of the US. Presently (1990 data), about 31 of the $85+$ exajoules consumed anmually in the US are used at temperatures of $250^{\circ} \mathrm{C}$ and less. Figure 5 shows the cumulative distribution function for this energy and indicates the temperature ranges of some of the applications. Note particularly the large component for space and water heating.

The question remains as to how much of $Q_{t}$ really can be exploited for the designated uses. In other words, how much of $Q_{U}$ is actually the HDR energy reserve? This is a question whose answer involves both technology and economics issues and the answer, at the moment, is none. The technology issues revolve primarily around the creation of the subterranean HDR reservoir and, to a lesser extent, the conversion and/or distribution process(es) in the accompanying surface facility. It has been clearly demonstrated, in both O\&G exploration and in LANL's and others' HDR experiments, that present-day O\&G drilling technology is more than capable of reaching depths to the $7 \mathrm{~km}$ assumed in computing $Q_{U}$, and existing hydrofracturing techniques are demonstrably applicable to creating downhole permeability. Yet, these are experimental applications, and expensive, insofar as $\mathrm{HDR}$ reservoir formation is concerned. Hence further ad hoc development and refinement of these technologies is needed. The surface facility, for electricity generation, would probably use a binary fluid Rankine cycle, although a double-flash system has also been discussed. Exchange of heat with a secondary fluid, most probably also water, would in most cases be necessary for DATE uses. Any improvements in the types and achievable efficiencies of these surface systems would enhance the potential for use of HDR energy.

Ultimately, the development decision boils down to economics, and at a very local level. HDR energy sources will be developed and exploited only where the energy produced would be at least price competitive with, if not cheaper than, that from alternative (most likely more conventional) suurces. It is not the intention of this report to develop again the theoretical economics of HDR energy. That has been done admirably and extensively by others, including Milora and Tester (1976), Cummings and Morris (1979), Murphy et al. (1982), Shock (1986), Hori et al. (1986), Armstead and Tester (1987), Entingh (1987), Bechtel (1988), 

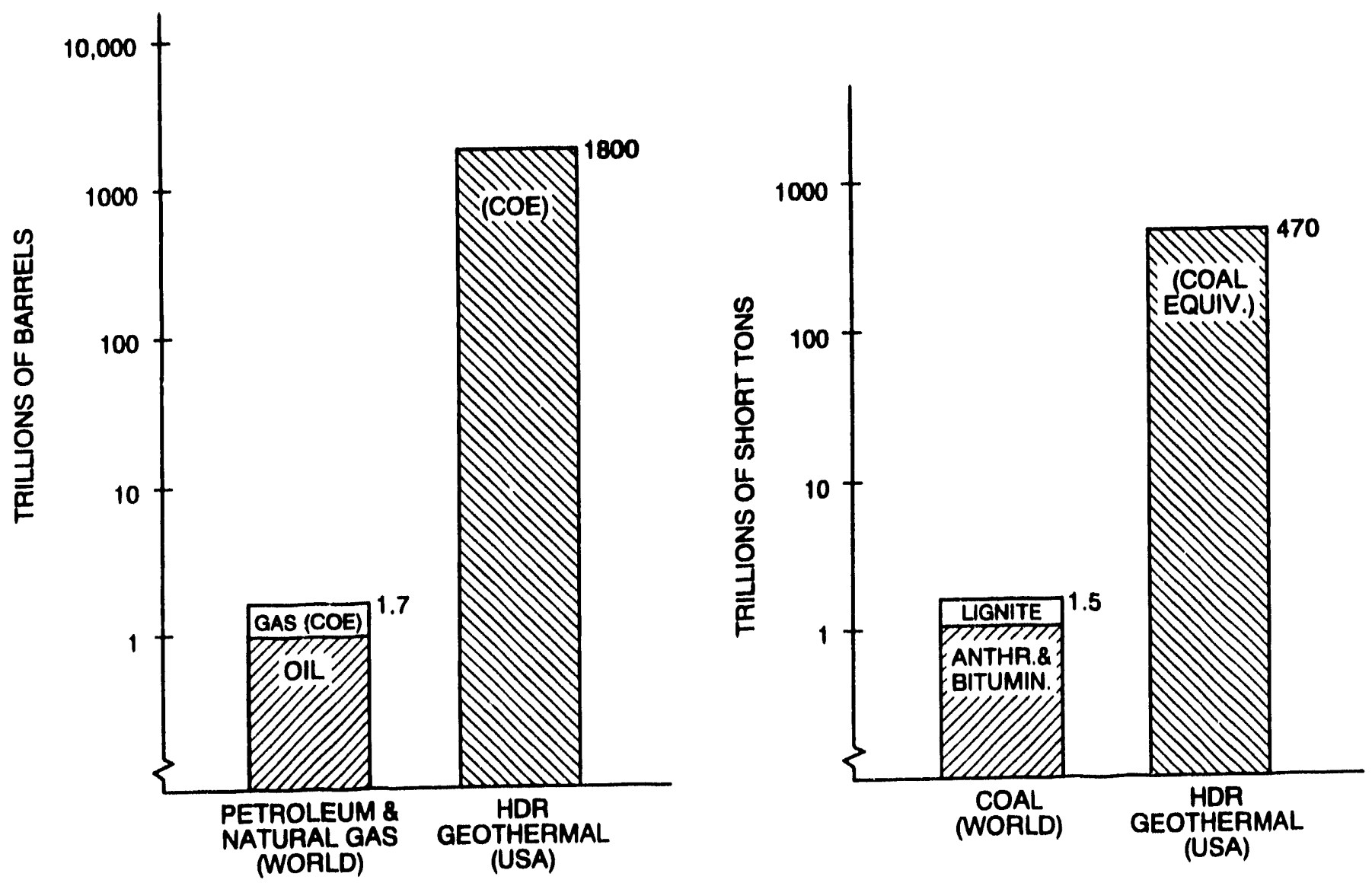

Fig. 4. Comparison of potentially useful HDR energy resource base of the US with projected" WORLD reserves of fossil fuels.

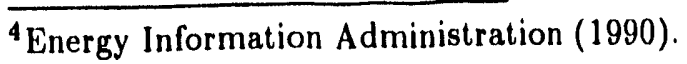


Tester et al. (1989), and, of particular note, the comprehensive review and analysis of these predecessors and revised economic modeling by Tester and Herzog (1990). However, the author feels that a few additional comments about the economics of HDR are in order:

(1) Although all of the aforementioned economic models assume that drilling cost is an exponential function of depth, Nunz and Murphy (1985) have shown, through analysis of Joint Association Survey data (1984) on some 200,000 onshore $O \& G$ wells, that drilling cost is actually a more slowly increasing polynomial function of depth. ${ }^{5}$ They have also shown a continuous improvement in HDR-related drilling costs with time, apparently trending toward convergence with O\&G drilling costs. These trends lend some optimism that the drilling component of HDR energy can approach that of conventional O\&G drilling. Further, future economics-motivated ad hoc improvements in HDR drilling technology and/or technique may significantly reduce this cost.

(2) The question of how much of the thermal energy in rock underlying a given area can actually be put to use must be technically, economically, and environmentally analyzed in detail for each local situation. However, we may obtain an optimistic upper bound by considering technical limitations, irrespective of cost. If we assume that the fractured regions created are roughly spherical and placed as close to each other as possible, about $52 \%$ of a given volume will be thermally accessed. For electricity generation, we might also assume that the surface process permits up to $20 \%$ temperature drawdown and involves a $20 \%$ average conversion cycle efficiency. Thus, about $2 \%$ of the local QUE could be produced as baseload electricity if the economics justified it. For the DA'TE component, the conversion (i.e., transfer) efficiency could be considerably higher, but the value of the lower-grade heat energy might not justify the volumetrically intensive drilling/fracturing campaign implicit in maximizing thermal accessibility to a given rock volume, making $2 \%$ not an unreasonable upper-limit estimate of the deliverable fraction of $Q U D$ as well. The degrees of exploitation ultimately realized, driven by local need and time-variant economics, will probably still be well below, perhaps by an order of magnitude or more, this $2 \%$ "soft" upper bound. Qualitatively speaking, one might expect that as time passes, a larger fraction of the high-grade resource base, a smaller fraction of the moderate- and lower-grade resource bases, and very little to none of the marginal resource base will be economically producible.

(3) HDR energy is a quasi-renewable resource. All of the aforementioned economic studies clearly indicate that if HDR energy is to be produced profitably, thermal energy must be extracted from the reservoir rock much more rapidly than it can be replaced by heat flowing up from the still hotter regions below. This limitation is a natural consequence of the low thermal conductivity of rock. However, over a sufficiently long time period and depending upon the degree of drawdown, the original temperature levels in the reservoir will be re-established and the reservoir could be used again. Hence, HDR energy development on a large scale might see some fraction of the individual reservoir units in a production complex "lying fallow" at any given time as they are being thermally recharged. Because the resource is so large and so widely distributed, this could become a very feasible mode for its exploitation.

Some states are blessed with a larger percentage of the higher-grade resource than others, as indicated by Table IV and on the Fig. 6 map showing each state's average areal density of the potentially useful resources, $\left(Q_{U} / A\right)$ avg. Development of the PEG component in the high-grade regions would not only produce baseload electricity at competitive prices in the near future, but the experience gained in creating these high-grade electricity generation systems in different parts of the country and in varying geological milieux would help to reduce the cost of subsequently developing the lower-grade DATE systems. Then, somewhat further in the future, as fossil fuel prices and the concomitant costs of environmental abatement inexorably increase, development of the lower-grade IDR resources would become profitable. In the meanwhile, engineering

5 Recently reconfirmed by the author by analysis of the JAS 1991 Drilling Costs data for onshore wells. 


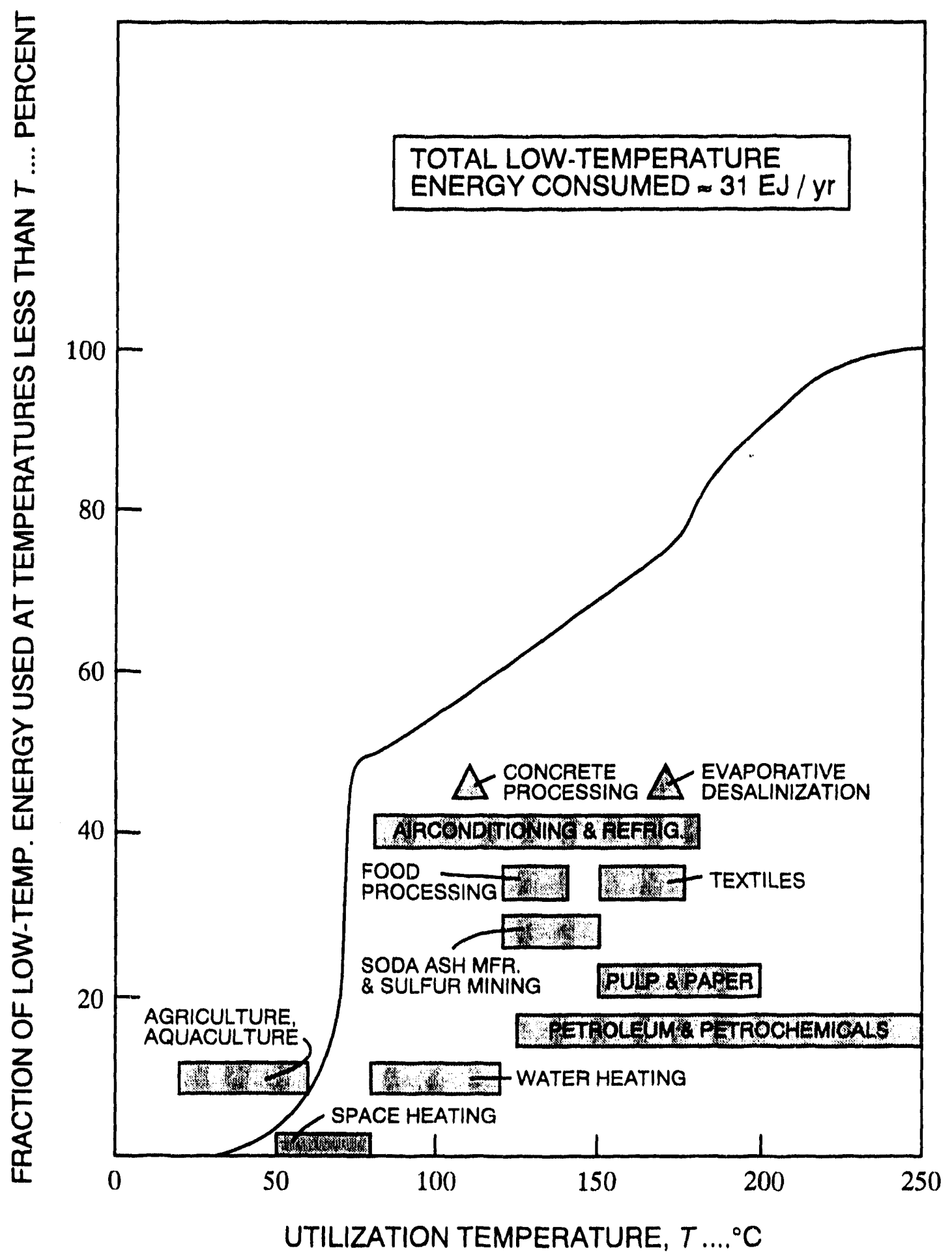

Fig. 5. Low-temperature energy use in the US and some typical applications. 
development of the HDR riservoir creation and production technologies must continue under broad and adequate sponsorship to achieve commercial readiness as soon as possible. 


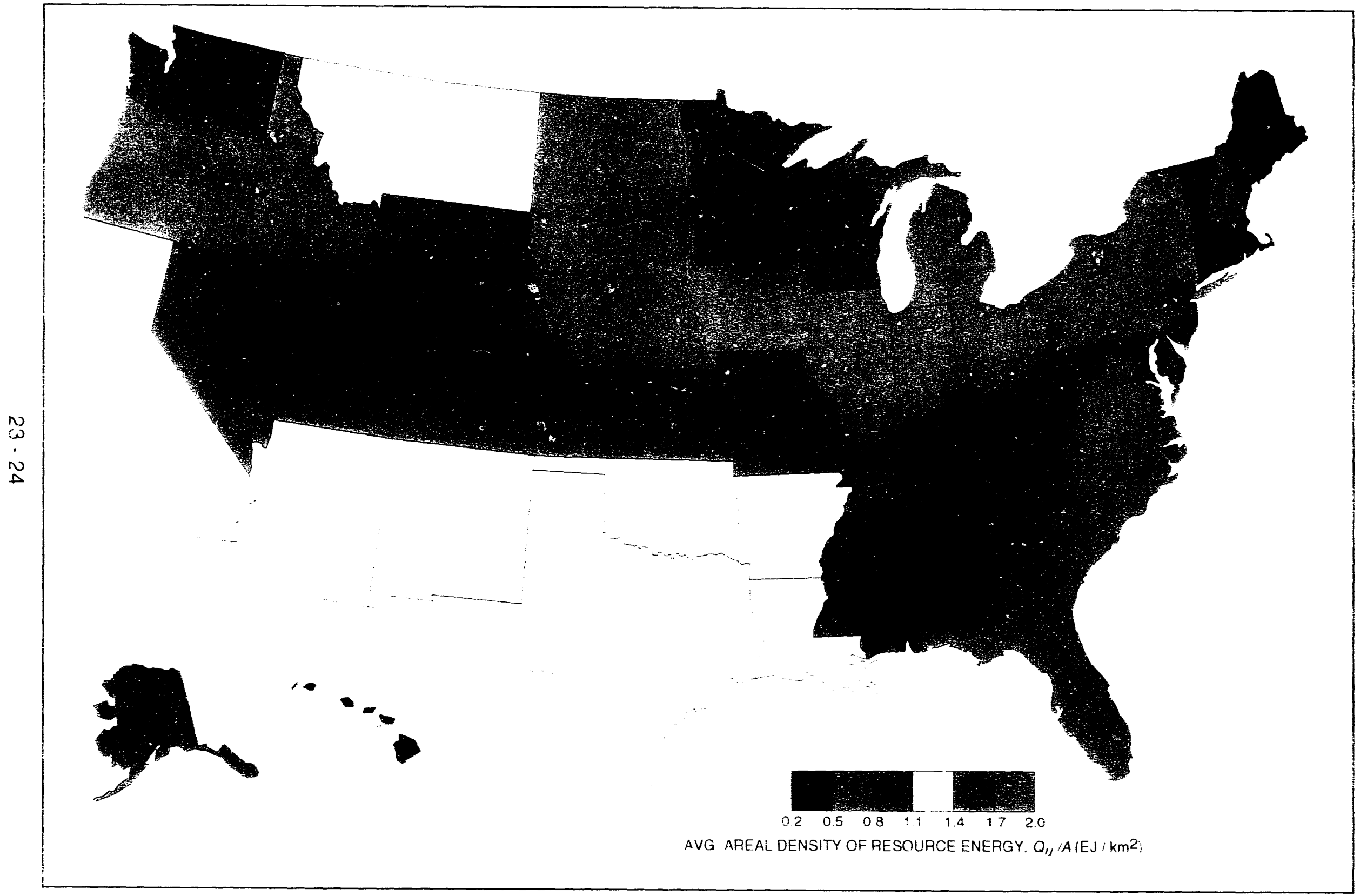

Fig. 6 State average areal densities of potentially useful HDR resource base 


\section{CONCLUSIONS AND RECOMMENDATIONS}

The data presented herein confirm previous assessments showing the enormity and ubiquity of the HDR energy resource. They strengthen the conclusion that the geographical distribution and quality of the resource are now known well enough for most of the United States to make reasonable assertions concerning the resource's applicability in specific locales.

As the world's political climate is currently developing, it is possible that a large part of the US petroleum supply could suddenly be cut off. In the interest of national security, it therefore behooves us to accelerate development of at least the capability to exploit major alternative energy sources if need. $d$. In the case of the HDR resource, scientific feasibility has been well demonstrated and comprehensive economic analyses have been performed, but these have employed several somewhat speculative assumptions. To foster commercial interest in, and exploitation of, this resource in the context of the American industrial culture, engineering development must be completed under governmental (federal and/or state and/or local) sponsorship. Specifically, and as a minimum

(1) the now-dormant Fenton Hill Project should be completed with a truly long-term flow test to provide needed data and/or verify predictions on reservoir drawdown rate, thermal stress cracking, impedance variation, scaling, and so on.

(2) at least one additional "pilot-plant-sized" engineering prototype HDR energy extraction system should be established in a geographically separate and geologically disparate high-grade region to validate the predicted economics, using the lessons learned from the experimental Fenton Hill system. 


\section{REFERENCES}

Armstead, H. C. H. and J. W. Tester, Heat Mining, (E. F. Spon, London, 1987).

Bechtel National, Inc., "Hot Dry Rock Venture Risks Investigation," final report to the US Dept. of Energy under Contract DE-AC03-86SF16385, San Francisco, CA (1988).

Cummings, R. G. and G. E. Morris, "Economic Modeling of Electricity Production from Hot Dry Rock Geothermal Reservoirs: Methodology and Analysis," EPRI report EPRI EA-630 (Palo Alto, CA; 1979).

Diment, W. H., T. C. Urgan, J. H. Sass, B. U. Marshall, R. J. Munroe, and A. H. Lachenbruch, "Temperatures and Heat Contents Based on Conductive Transport of Heat," in US Geological Survey Circular 726 (1975).

Energy Information Administration, "Energy Facts 1990," US Dept. of Energy report DOE/EIA-0469(90) (Washington, DC; 1990).

Entingh, D., "Historical and Future Cost of Electricity from Hydrothermal Binary and Hot Dry Rock Reservoirs, 1975-2000," Meridian Corp. report 240-GG (Alexandria, VA; 1987).

Electric Power Research Institute, "Geothermal Energy Prospects for the Next 50 Years," EPRI report EPRI ER-611-SR (1978).

Grossling, B. F., "An Appraisal of the Prospects of Geothermal Energy in the United States," in US Energy Outlook (National Petroleum Council; Washington, DC; 1972).

Heiken, G., F. Goff, and G. Cremer, Eds., "Hot Dry Rock Geothermal Resource 1980," Los Alamos National Laboratory report LA-9295-HDR (Los Alamos, NM; 1982).

Heiken, G., H. Murphy, G. Nunz, R. Potter, and C. Grigsby, "Hot Dry Rock Geothermal Energy," American Scientist, 69, (4), 400-407 (July-August 1981).

Hickel, W. J., "Geothermal Energy," in Geothermal Resources Research Conference Final Report (Univ. of Alaska Press; Fairbanks, AK; 1972).

Ho, C. Y., R. W. Powell, and C. E. Liley, "Thermal Conductivity of Rocks," Journal of Physical and Chemical Reference Data 1, (Amer. Inst. of Physics/Amer. Chem. Soc., 1972).

Hori, Y. et al. "On [the] Economics of [a] Hot Dry Rock Geothermal Power Station," HDR Geothermal Power Station Cost Study Committee report 385001 (Corporate Foundation Central Research Institute for Electric Power, Japan; March 1986).

Joint Association Survey on Drilling Costs 1989 (American Petroleum Institute; Washington, DC; November 1984).

Kron, A. and J. Stix, "Geothermal Gradient Map of the United States," map produced by the National Oceanic and Atmospheric Administration for Los Alamos National Laboratory, Los Alamos, NM (1982).

Kron, A., K. H. Wohletz, and J. E. Tubb, "Geothermal Gradient Contour Map of the United States," Los Alamos National Laboratory map, (Los Alamos, NM; 1991).

LASL HDR Project Staff, "Hot Dry Rock Geothermal Energy Development Project, Annual Report for Fiscal Year 1977," Los Alamos Scientific Laboratory report LA-7109-PR (Los Alamos, NM; February 1978).

Lindroth, D. P. and J. Kranza, "Heat Content and Specific Heat of Six Rock Types at Temperatures to $1000^{\circ} \mathrm{C}$," Report of Investigations 7503, Bureau of Mines (US Government Printing Office; Washington, DC; 1971).

McGetchin, T. R., "Hot Dry Rock Geothermal Energy: Status of Exploration and Assessment," Hot Dry Rock Assessment Panel Report No. 1, ERDA report ERDA-77-74 (Washington, DC; 1977).

Milora, S. L. and J. W. Tester, Geothermal Energy as a Source of Electric Power (MIT Press; Cambridge, MA; 1976).

Military Engineering Vol. XV: Applied Geology for Engineers (Ministry of Defense/Institute of Civil Engineers 71044; Her Majesty's Stationary Office; London, England; 1976). 
Muffler, L. J. P., Ed., "Assessment of Geothermal Resources of the United States-1978," US Geological Survey Circular 790 (Arlington, VA; 1979a).

Muffler, L. J. P., "Summary, Hot Dry Rock," in US Geological Survey Circular 790 (1979b).

Murphy, H. D., R. Drake, J. W. Tester, and G. A. Zyvoloski, "Economics of a 75-mWe Hot Dry Rock Geothermal Power Station Based upon the Design of the Phase II Reservoir at Fenton Hill," Los Alamos National Laboratory report LA-9241-MS (Los Alamos, NM; 1982).

Nathenson, M. and M. Guffanti, "Geothermal Gradients in the Conterminous United States," Journal of Geophysical Research 93 (B6), 6437-6450 (June 1988).

Nathenson, M. and L. J. P. Muffler, "Geothermal Resources in Hydrothermal Convection Systems and Conduction-Dominated Areas," in US Geological Survey Circular 726 (1975).

National Petroleum Council, U.S. Energy Outlook-New Energy Forms, US Government Printing Office; Washington, DC; 1973).

Nunz, G. J., "The D.O.E. Hot Dry Rock Program," Second DOE-ENEL Workshop for Cooperative Research in Geothermal Energy; Berkeley, CA; October 1980; Los Alamos Scientific Laboratory document LA-UR80-2991.

Nunz, G. J. and P. R. Franke, "HDR Geothermal Energy-A Progress Report," Geothermal Resources Council 1983 Annual Meeting; Portland, OR; October 1983; Los Alamos National Laboratory document LA-UR-83-1659.

Nunz, G. J. and P. R. Franke, "Present Status of Hot Dry Rock Technology," in Alternative Energy Sources VII: Vol. 3 Indirect Solar/Nuclear (Hemisphere Publishing Co.; New York, NY; 1987).

Nunz, G. J. and H. D. Murphy, "Drilling Cost Statistics," Los Alamos National Laboratory internal memorandum to EPRI Study Support Team (Los Alamos, NM; April 1985).

Perry, J. H., Ed., Chemical Engineers' Handbook, 6th ed., (McGraw-Hill; New York, NY; 1984).

Rex, R. W. and D. J. Howell, "Assessment of U.S. Geothermal Resources," in Geothermal Energy, P. Kruger and C. Otte, Eds. (Stanford Univ. Press; Stanford, CA; 1973).

Shock, R. A. W., "An Economic Assessment of Hot Dry Rocks as an Energy Source for the U.K.," Energy Technology Support Unit report ETSU-R-34 (UKDOE; Oxfordshire, UK; 1986).

Smith, M. C., "The Hot Dry Rock Geothermal Energy Program," Los Alamos National Laboratory Minireview LALP-87-16 (Los Alamos, NM; Sept. 1987).

Smith, M. C., R. L. Aamodt, R. M. Potter, and D. W. Brown, "Man-Made Geothermal Reservoirs," in Proc. of the 2nd United Nations Symposium on the Development and Use of Geothermal Resources (Lawrence Berkeley Laboratory; San Francisco, CA; 1975) Vol. 3, p. 178.

Stacey, F. D., Physics of the Earth (John Wiley \& Sons; New York, NY; 1969).

Tester, J. W., "Issues Facing the Development of Hot Dry Rock Geothermal Resources," 3rd Annual EPRI Geothermal Conference; Monterey, CA; June 1979; Los Alamos Scientific Laboratory document LA-UR79-1545.

Tester, J. W., D. W. Brown, and R. M. Potter, "Hot Dry Rock Geothermal Energy-a New Energy Agenda for the 21st Century," Los Alamos National Laboratory report LA-11514-MS (Los Alamos, NM; July 1989).

Tester, J. W. and C. O. Grigsby, "Geothermal Energy," in Kirt-Othmer: Encyclopedia of Chemical Technology, Vol. 11, 3rd ed., (John Wiley \& Sons; New York, NY; 1980).

Tester, J. W. and H. J. Herzog, "Economic Predictions for Heat Mining: a Review and Analysis of Hot Dry Rock (HDR) Geothermal Energy Technology," MIT Energy Laboratory report MIT-EL90-001 (Massachusetts Institute of Technology; Cambridge, MA; July 1990).

US Dept. of Commerce, Bureau of Census, Statistical Abstract of the United States: 1991, 111th ed. (US Government Printing Office; Washington, DC; 1991). 
White, D. E., Ed., US Geological Survey Circular 519 (Arlington, VA; 1965).

White, D. E. and Williams, D. L., Eds., "Assessment of the Geothermal Resources of the United States1975," US Geological Survey Circular 726 (Arlington, VA; 1975). 


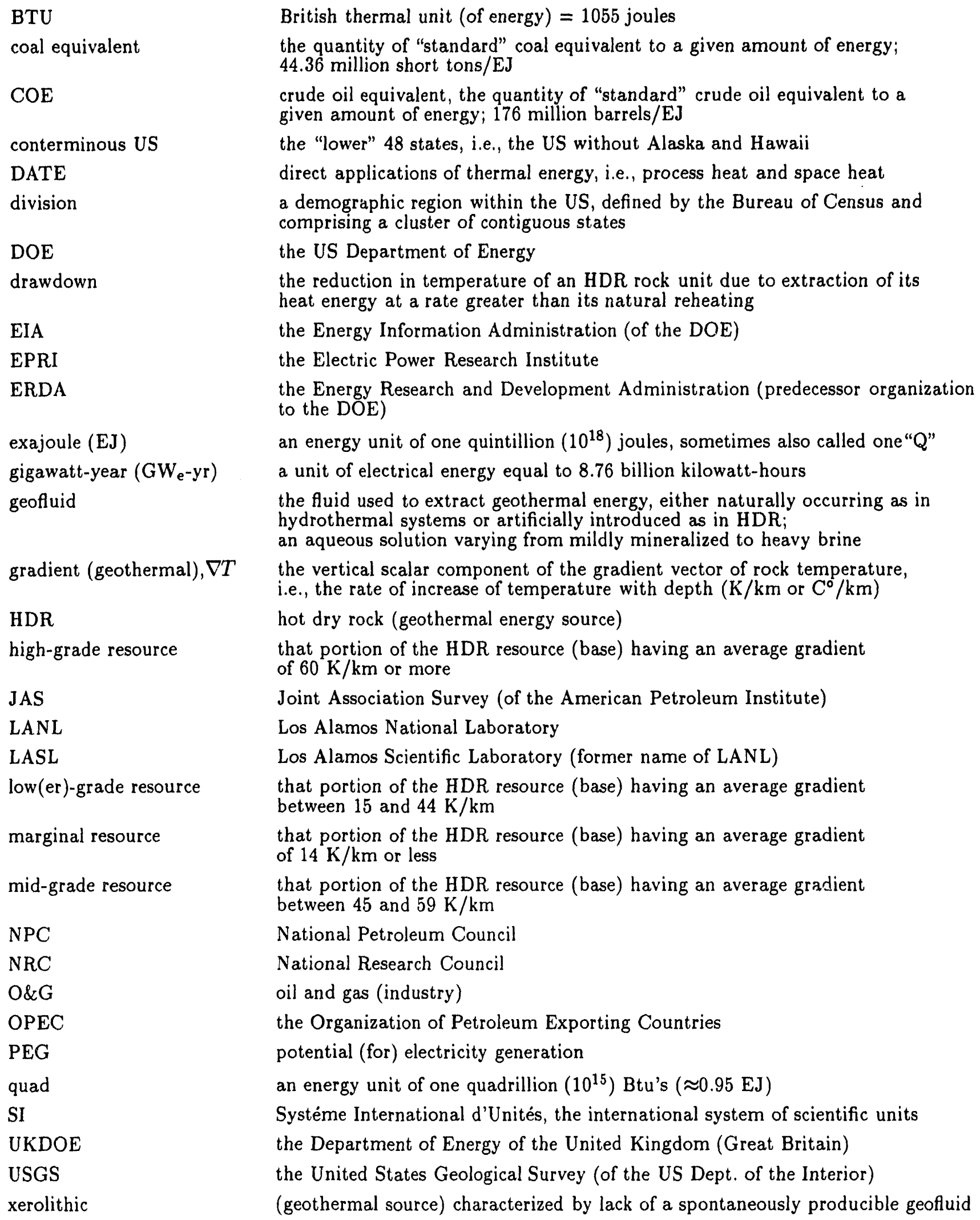

British thermal unit (of energy) $=1055$ joules

the quantity of "standard" coal equivalent to a given amount of energy; 44.36 million short tons/EJ

crude oil equivalent, the quantity of "standard" crude oil equivalent to a given amount of energy; 176 million barrels/EJ

the "lower" 48 states, i.e., the US without Alaska and Hawaii

direct applications of thermal energy, i.e., process heat and space heat

a demographic region within the US, defined by the Bureau of Census and comprising a cluster of contiguous states

the US Department of Energy

the reduction in temperature of an HDR rock unit due to extraction of its heat energy at a rate greater than its natural reheating

the Energy Information Administration (of the DOE)

the Electric Power Research Institute

the Energy Research and Development Administration (predecessor organization to the DOE)

an energy unit of one quintillion $\left(10^{18}\right)$ joules, sometimes also called one " $Q$ "

a unit of electrical energy equal to 8.76 billion kilowatt-hours

the fluid used to extract geothermal energy, either naturally occurring as in hydrothermal systems or artificially introduced as in HDR; an aqueous solution varying from mildly mineralized to heavy brine

the vertical scalar component of the gradient vector of rock temperature, i.e., the rate of increase of temperature with depth $\left(\mathrm{K} / \mathrm{km}\right.$ or $\left.\mathrm{C}^{\circ} / \mathrm{km}\right)$

hot dry rock (geothermal energy source)

that portion of the HDR resource (base) having an average gradient of $60 \mathrm{~K} / \mathrm{km}$ or more

Joint Association Survey (of the American Petroleum Institute)

Los Alamos National Laboratory

Los Alamos Scientific Laboratory (former name of LANL)

that portion of the HDR resource (base) having an average gradient between 15 and $44 \mathrm{~K} / \mathrm{km}$

that portion of the HDR resource (base) having an average gradient of $14 \mathrm{~K} / \mathrm{km}$ or less

that portion of the HDR resource (base) having an average gradient between 45 and $59 \mathrm{~K} / \mathrm{km}$

National Petroleum Council

National Research Council

oil and gas (industry)

the Organization of Petroleum Exporting Countries

potential (for) electricity generation

an energy unit of one quadrillion $\left(10^{15}\right)$ Btu's $(\approx 0.95 \mathrm{EJ})$

Systéme International d'Unités, the international system of scientific units the Department of Energy of the United Kingdom (Great Britain) the United States Geological Survey (of the US Dept. of the Interior) (geothermal source) characterized by lack of a spontaneously producible geofluid

\section{Appendix A. Glossary}




\section{Appendix B. Resource Base Computation Algorithms}

The quantity of heat energy, $d Q$, stored in an element of rock volume, $d V$, at a temperature, $T$, above a reference temperature, $T_{\text {ref, }}$ is .

$$
d Q=\rho C_{p}\left(T-T_{r e f}\right) d V,
$$

where $\rho$ is the mass density and $C_{p}$ is the specific heat of the rock element. The total energy contained within a part of a spherical shell, in earth-centered latitude/longitude coordinates, is given by the integral of equation (B1)

$$
Q=-\int_{r} \int_{\theta} \int_{\lambda} \rho C_{p}\left(T-T_{r e}\right) r^{2} \cos \lambda d \lambda d \theta d r
$$

in which $r$ is the radius variable; $\lambda$ and $\theta$ are latitude and longitude variables, respectively, which define the surface boundaries of the region in question; and the negative sign accommodates the integration from the surface to smaller radii. As in previous calculations of this nature, and specifically for use of geothermal gradient map of Fig. 2, equation (B2) is reduced to a simplified computational algorithm via several approximations:

1. The shell segments are thin (relative to earth radii); hence we may revert to surface-based Cartesian coordinates with the positive z-axis (depth) downward.

2. A constant average gradient $\nabla T_{i}$, invariant within the $i$ th contour interval on the geothermal gradient map to the depth limits of the resource bases, is assumed, as well as a fixed mean annual surface temperature, $T_{0}$. These assumptions result in a linear relationship between temperature and depth, $z$, within the ith contour interval, as noted in Section 3.3.

$$
T_{i}(z)=T_{0}+\nabla T_{i} z \quad\left({ }^{\circ} \mathrm{C}\right),
$$

with $T_{0}=15^{\circ} \mathrm{C}$, for $\nabla T$ in $\left(\mathrm{K}\right.$ or $\left.{ }^{\circ} \mathrm{C} / \mathrm{km}\right)$ and $z$ in kilometers.

3. Within each state, the incremental area

$$
\Delta A_{i}=\iint_{S_{i}} d A \quad\left(\mathrm{~km}^{2}\right)
$$

contained in the contour interval $S_{i}$ is determined by graphical integration.

4. The volumetric-specific heat of rock, represented by the product $\rho C_{p}$, varies with the rock's mineralogic composition, porosity, fluid content, temperature, and confining pressure. Because it is assumed that we are dealing largely with relatively impermeable and dry granitic crystalline rock, the porosity and fluid effects may be neglected. Further, to a depth of $10 \mathrm{~km}$ or less, the compressibility effect is also second-order and can be ignored. Review of the assumptions and recommendations from the literature (Perry [1984], Stacey [1969], Lindroth and Kranza [1971], Military Engineering [1976], Ho et al. [1988]) used in prior resource calculations indicates that we may take as a constant representative average rock density over the range of compositions and conditions of interest

$$
\bar{\rho} \approx 2600\left(\mathrm{~kg} / \mathrm{m}^{3}\right)=2.60 \times 10^{12}\left(\mathrm{~kg} / \mathrm{km}^{3}\right)
$$

and a temperature-dependent average specific heat

$$
C_{p}(T) \approx 807 .+0.690 T(\mathrm{~J} / \mathrm{kg}-\mathrm{K})
$$

Combining the temperature/depth equation (B3) with this average $C_{p}$ relation and multiplying by $\bar{\rho}$ yields an expression for depth-dependent average volumetric-specific heat in the $i$ th contour interval region 


$$
\overline{\rho C_{p}}(z)_{i} \approx 2.12 \times 10^{-3}+1.79 \times 10^{-6} \nabla T_{i} z\left(\mathrm{EJ} / \mathrm{km}^{3}-\mathrm{K}\right)
$$

With the approximations (1) through (4), using equations (B3), (B4), and (B5), the computational form of equation (B2) becomes

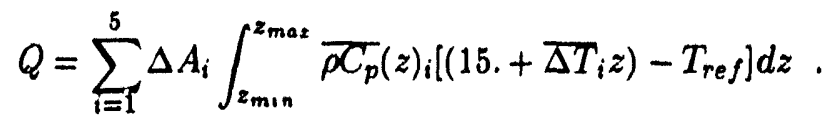

To calculate $Q_{B}, Q_{A}$ and the components of $Q_{U}$, as indicated in Section 3.3, the values of $T_{r e f}$ and of the limits of integration, $z_{\min }$ and $z_{\max }$, used with equation (B6) were as follows:

\begin{tabular}{lclll} 
Resource Base Calculated & $T_{\text {ref }}\left({ }^{\circ} \mathrm{C}\right)$ & & $z_{\min }(\mathrm{km})$ & \\
\cline { 1 - 2 } total, $Q_{B}$ & 15. & 0. & 10. \\
accessible, $Q_{A}$ & 25. & $z\left(25^{\circ} \mathrm{C}\right)$ & 7. \\
potentially useful PEG, $Q_{U E}$ & 40. & $z\left(150^{\circ} \mathrm{C}\right)$ & $\min \left[7 ., z\left(374^{\circ} \mathrm{C}\right)\right]$ \\
process heat, QUP & 40. & $z\left(100^{\circ} \mathrm{C}\right)$ & $\min \left[7 ., z\left(150^{\circ} \mathrm{C}\right)\right]$ \\
space heat, $Q_{U S}$ & 40. & $z\left(60^{\circ} \mathrm{C}\right)$ & $\min \left[7 ., z\left(100^{\circ} \mathrm{C}\right)\right]$
\end{tabular}




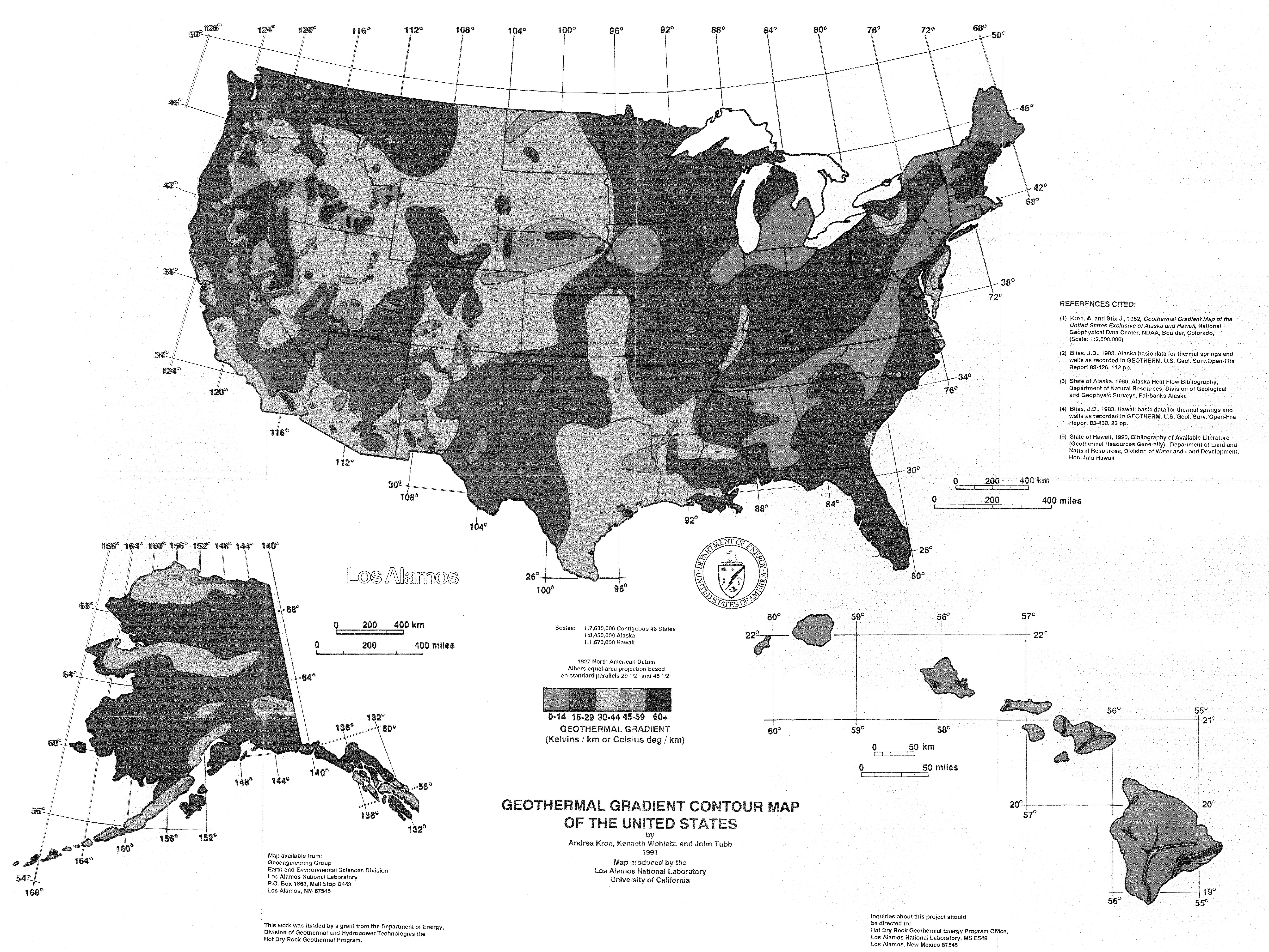

